\title{
This Mine is Mine! How Minerals Fuel Conflicts in Africa ${ }^{\dagger}$
}

\author{
By Nicolas Berman, Mathieu Couttenier, Dominic Rohner, \\ and Mathias Thoenig*
}

\begin{abstract}
We combine georeferenced data on mining extraction of 14 minerals with information on conflict events at spatial resolution of $0.5^{\circ} \times 0.5^{\circ}$ for all of Africa between 1997 and 2010. Exploiting exogenous variations in world prices, we find a positive impact of mining on conflict at the local level. Quantitatively, our estimates suggest that the historical rise in mineral prices (commodity super-cycle) might explain up to one-fourth of the average level of violence across African countries over the period. We then document how a fighting group's control of a mining area contributes to escalation from local to global violence. Finally, we analyze the impact of corporate practices and transparency initiatives in the mining industry. (JEL C23, D74, L70, O13, Q34)
\end{abstract}

Natural riches such as valuable minerals have often been blamed for fueling armed fighting. A case that recently made headlines is the heavy fighting that broke out between the Rizeigat and Bani Hussein, two Arab tribes, for territorial control of the Jebel Amer gold mine in Darfur region. The conflict has killed more than

\footnotetext{
* Berman: Aix-Marseille University, CNRS, EHESS, Centrale Marseille, AMSE, Graduate Institute Geneva, and CEPR (e-mail: nicolas.berman@univ-amu.fr); Couttenier: University of Geneva (previously: University of Lausanne) (e-mail: mathieu.couttenier@unige.ch); Rohner: Department of Economics, University of Lausanne, and CEPR (e-mail: dominic.rohner@unil.ch); Thoenig: Department of Economics, University of Lausanne, and CEPR (e-mail: mathias.thoenig@unil.ch). We thank five anonymous referees, as well as Gani Aldashev, Chris Blattman, Paola Conconi, Ruben Enikopolov, Nicola Gennaioli, Gianmarco Leon, Thierry Mayer, Hannes Mueller, Paolo Pinotti, Uwe Sunde, and Oliver Van den Eynde, and seminar and conference audiences in Oxford (OxCarre), Aix-Marseille, Bern, Bonn, Ente Einaudi, Geneva, Graduate Institute, IPEG Pompeu Fabra, Lyon, Montpellier, Paris, Universitat Autonoma de Barcelona, Uppsala, Warwick, ABCA 2015 Berkeley, IEA World Congress Jordan, Workshop on the Geography of Civil Conflict in Munich, the Conference on the Political Economy of Conflict and Development in Villars, the Workshop on Conflict at Bocconi University, the CAVE Workshop at Prio, and the workshop on the Political Economy of Development and Conflict IV in Barcelona for very useful discussions and comments. Special thanks to Elissaios Papyrakis for sharing with us his data on EITI membership. Quentin Gallea, Valentin Muller, Andre Python, Jingjing Xia, and Nathan Zorzi provided excellent research assistance. Nicolas Berman thanks the A*Midex for financial support (grant ANR-11-IDEX-0001-02 funded by the French government Investissement d'Avenir program). Mathieu Couttenier acknowledges financial support from the Swiss National Fund for Research. Mathieu Couttenier and Mathias Thoenig acknowledge financial support from the ERC Starting grant GRIEVANCES-313327. Dominic Rohner acknowledges financial support from the ERC Starting grant POLICIES FOR PEACE-677595. This paper features an online Appendix containing additional results and data description. The authors declare that they have no relevant or material financial interests that relate to the research described in this paper.

Go to https://doi.org/10.1257/aer.20150774 to visit the article page for additional materials and author disclosure statement(s).
} 


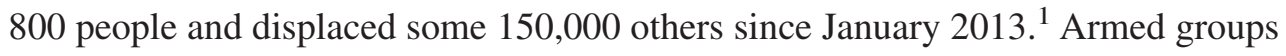
extract revenues from mines without necessarily directly managing them, and extortion and bribery have been widely documented in mineral-abundant conflict areas. An example is the financial and logistical support provided by the mining company AngloGold Ashanti in 2003-2004 to the Nationalist and Integrationist Front (FNI), a rebel group operating in the gold-rich district of Ituri in eastern DRC. ${ }^{2}$

The present paper investigates the impact of mining on conflict by using geolocalized data on conflict events and mining extraction of 14 minerals for all African countries over the 1997-2010 period. Our results show that mining activity increases the incidence of conflicts at the local level and then spreads violence across territory and time by enhancing the financial capacities of fighting groups. Our empirical analysis is based on the combination of an original dataset, Raw Material Data (RMD), documenting the location and the types of mines and minerals, with the Armed Conflict Location Events Data (ACLED), containing information on the location and type of conflict events and the involved actors. The units of analysis are cells of $0.5 \times 0.5$ degree latitude and longitude (approximately $55 \mathrm{~km} \times 55 \mathrm{~km}$ at the equator) covering all of Africa. The use of georeferenced information enables causal identification. Including country $\times$ year fixed effects and cell fixed effects, we exploit in most of our econometric specifications the within-mining area panel variations in violence due to changes in the world price of the main mineral extracted in the area.

In the first part of our analysis, we estimate the overall extent of mining-induced violence at the local level. We find a positive effect of mining activity on conflict probability: a spike of mineral prices increases conflict risk in cells producing these commodities. These results are robust to a variety of consistency checks. We also find that countries with less corrupt institutions and with lower religious fractionalization/polarization are less affected by mining-induced violence; however, we detect little effect of political institutions (e.g., democracy, rule of law, government effectiveness). Similarly we find that minerals associated with higher rents are particularly conflict-prone. We then perform several quantification exercises to gauge the magnitude of the effect. A one-standard deviation increase in the price of minerals translates into an increase in probability of violence in mining areas from the benchmark 16.9 percent to a counterfactual 22.5 percent. When aggregated at the country level, the effect remains sizable. Indeed we quantify the effect of the historical rise in mineral prices between 1997 and 2010, which according to most

\footnotetext{
${ }^{1}$ Fighters from the Sudan Liberation Army (SLA) have operated their own illicit gold mine in Hashaba to the east of Jebel Amer to finance their fighting. Other prominent examples of rebels sustaining their fighting efforts with the cash from running mines include rebel groups operating in Sierra Leone and Liberia, such as the Revolutionary United Front (RUF) that financed weaponry with "blood diamonds" (Campbell 2002), or Angola's rebels from União Nacional para a Independencia Total de Angola (UNITA) that financed their armed struggle with diamond money (Dietrich 2000). See “Special Report: The Darfur Conflict's Deadly Gold Rush,” Reuters, October 8, 2013. Another example is the Marikana Mine Massacre, where in 2012 several dozen people were shot in a wildcat strike at a platinum mine owned by Lonmin in the Marikana area, close to Rustenburg, South Africa. See "South African Mine Owner Amplats Fires 12,000 Workers,” BBC, October 5, 2012.

2 "D.R. Congo: Gold Fuels Massive Human Rights Atrocities," Human Rights Watch brief, June 5, 2005. For the complete report, see Human Rights Watch (2005, p. 65). AngloGold Ashanti have been accused of having established a relationship with the FNI "who had effective control over the Mongbwalu gold mining area, to facilitate their gold exploration activities." This relationship involved payments of bribes as well as logistical support, in particular through the transportation of FNI leaders.
} 
scholars was mainly due to the sharp increase in the demand for minerals by emerging market countries such as China and India (Humphreys 2010; Carter, Rausser, and Smith 2011). Our estimates suggest that the contribution of this so-called commodities super-cycle to the average violence observed across African countries over the period lies between 14 percent and 24 percent.

In the second part of the paper we take a more global view and investigate the diffusion over space and time of mining-induced violence, a question of central importance for understanding how local conflicts escalate into regional or national wars. Looking at the nature of violent events, we find that mineral price spikes fuel both low-level violence (riots, protests) and organized violence (battles). The rationales behind each type of violence being different, we focus on battles involving African rebel groups over the period, and provide evidence that mines spread conflict across space and time by making rebellions financially feasible. More precisely, we first show that spikes in the price of minerals extracted in the ethnic homeland of a rebel group tend to diffuse its fighting operations spatially outside its homeland. As a second and alternative strategy, we make use of the information contained in the ACLED data on the winners and losers of particular battle events. We show that the appropriation of a mining area by a rebel group increases the probability that this group perpetrates violence elsewhere in the country in the following years. Quantitatively, our estimates suggest that every conquest of a mining area triples the subsequent fighting activity of a group.

Having documented how mining allows rebel groups to expand their fighting activities, we show in the last part of the paper that the characteristics and behavior of extracting companies also are key. Mining companies have an ambivalent role. On the one hand, they may be willing to secure areas where they plan to operate; on the other hand, they may contribute to the diffusion of violence by financing/bribing rebel groups. We provide suggestive evidence in line with the second channel. Our results show that mining-induced violence is associated mainly with foreign ownership. Nevertheless, among foreign companies, the ones that operate in the least corrupt countries, and the ones that comply with corporate social responsibility practices are associated with less violence. Finally, we evaluate the impact of the recent transparency/traceability initiatives that have been promoted by international agencies, and find some evidence that these top-down policies have been able to reduce the conflict risk.

Our paper contributes to the literature in several ways. First, we study resource abundance and conflict (i) for all major minerals; (ii) using data at a high spatial resolution; (iii) covering all Africa; and (iv) going beyond pooled panel regressions. Second, we provide direct, large-scale evidence of how capturing a mining area affects the diffusion of conflict over space and time. This yields findings that are in line with the view that resource rents can fuel diffusion of fighting by making it feasible to sustain rebellion. Third, to the best of our knowledge we are the first ones to document how mining company characteristics and practices (e.g., size, location of headquarters, compliance to Corporate Social Responsibility) can contain or boost mining-induced violence.

The paper is organized as follows. Section I discusses the existing literature and the conceptual framework that underpins our empirical analysis. Section II presents the data. Section III displays the empirical analysis related to the local impact of 
mining activity on violence and how it varies with country and mineral characteristics, as well as with the types of violent events. In Section IV we study the diffusion over space and time of mining-induced violence perpetrated by rebel groups. Section V studies the role of mining companies and of transparency initiatives, and Section VI concludes.

\section{Existing Evidence and Conceptual Framework}

In the last ten years the empirical literature has shown an increasing interest in linking natural resource abundance to civil conflict and other forms of violence..$^{3}$ Most existing papers have estimated pooled cross-country regressions finding that civil war onset and incidence correlate positively with natural resources, generally focusing on oil, diamonds, or narcotics. $\rrbracket^{4}$ The main shortcoming of this first generation of papers is that resource-rich and resource-poor countries typically differ also in various geographic, demographic, political, and economic dimensions, and the existence of unobserved heterogeneity complicates the causal interpretation of such cross-country correlations.

A more recent literature tries to address this issue through the use of panel data and the inclusion of country fixed effects, focusing on variations in prices or resource discoveries as an identification device. This has led to contradictory results. While Lei and Michaels (2014) find a positive effect of oil discoveries on conflict, Cotet and Tsui (2013) find that oil discoveries no longer show an effect on conflict when controlling for country fixed effects. Commodity price shocks also have an unclear effect on conflict, and are found in particular to be unrelated to conflict onsets (Bazzi and Blattman 2014). One of the reasons for these contradictory results could be that using the country-year level as the unit of observation is just too aggregate, since in many countries conflicts are concentrated in certain regions (such as the Niger delta in Nigeria or the Kurdish part of Turkey). Given this within-country heterogeneity, aggregating information into a country-year panel may lead to noisy estimates and hence attenuation bias. Recently, some papers have used disaggregated data on natural resources and conflict for one particular country, such as Dube and Vargas (2013) on oil in Colombia; Aragón and Rud (2013) on a gold mine in Peru; Maystadt et al. (2014) on minerals in the DRC; and Sanchez de la Sierra (2015) on coltan and gold in Eastern Congo. However, so far there does not exist a study of the nexus between natural resources and conflict based on a panel of disaggregated cells covering all minerals and a whole continent (Africa), as in the current paper. This feature yields a big gain in terms of external validity.

From a conceptual perspective, a rich theoretical literature has identified several major channels through which natural resources magnify the risk of conflict: a survey relevant for our analysis being provided by Bazzi and Blattman (2014). First, natural

\footnotetext{
${ }^{3}$ Natural resources have also been found to empirically matter for homicides (Couttenier, Grosjean, and Sangnier forthcoming), for organized crime (Buonanno et al. 2015), for interstate wars (Caselli, Morelli, and Rohner 2015), and for mass killings of civilians (Esteban, Morelli, and Rohner 2015).

${ }^{4}$ See De Soysa (2002), Fearon and Laitin (2003), Ross (2004, 2006), Fearon (2005), and Humphreys (2005) in the case of oil; Lujala, Gleditsch, and Gilmore (2005), Humphreys (2005), Ross, (2006), and Lujala (2010) focusing on diamonds; and Angrist and Kugler (2008) and Lujala (2009) on narcotics. Collier and Hoeffler (2004) provide evidence more generally related to primary commodities. This cross-country literature has also found that lootable resources (e.g., alluvial gemstones, narcotics) prolong conflicts (Fearon 2004; Ross 2004, 2006; Lujala 2010).
} 
resources improve rebellion feasibility, i.e., looting and extortion relax financing constraints and make it easier to set up and sustain a rebel movement. Second, the presence of natural resources increases the prize to be seized through the capture of the territory or the state, a practice referred to as greed or rent-seeking. Third, weak state capacity and extractive institutions may be a further consequence of resource wealth. Rentier states can rely on resource rents and do not develop enough state capacity and good institutions, making them less effective in counterinsurgency and eventually more unstable. Fourth, given that natural resource production is capital-intensive, a resource price spike will boost capital-intensive production and shrink labor-intensive sectors, which frees up cheap labor for rebellion. Fifth, natural resources can exacerbate grievances, due to frustrations from environmental degradation or banned access to lucrative mining jobs. Sixth, mining booms could affect migration patterns and lead to changes in the size and composition of the local population in mining areas with respect to ethnicity, age, and gender. ${ }^{5}$ Finally, there is a channel working in the opposite direction: higher local incomes in mining areas may increase the opportunity cost of rebellion, which in turns decreases the likelihood of conflict.

The existing empirical literature typically has been unable to distinguish between these different theoretical mechanisms. ${ }^{6}$ In the first part of the paper, we document a positive causal impact of mineral prices' variations on conflicts, which is consistent with all the mechanisms mentioned above (except the last one). However, in the second part of the paper we focus specifically on the feasibility channel. In particular, we find that territorial control of mining areas leads rebel groups to spread their fighting elsewhere in successive periods. We also find that foreign mining companies operating in corrupt environments trigger more conflict, which is a piece of suggestive evidence on the participation of these companies in financing rebel groups. Overall, we see these results as supporting the existence of the feasibility channel. But in no way does this finding preclude that other mechanisms concurrently are at work.

\section{Data}

\section{A. Data Description}

The structure of the dataset is a full grid of Africa divided in subnational units of $0.5 \times 0.5$ degrees latitude and longitude $($ which means around $55 \times 55$ kilometers at the equator). We use this level of aggregation rather than administrative boundaries to ensure that our unit of observation is not endogenous to conflict events. 7 Our unit of observation therefore is a cell-year in Sections III and V; that is, we study how mineral resources affect the probability that a conflict takes place in a given cell

\footnotetext{
${ }^{5}$ For feasibility, see Fearon (2004), Collier, Hoeffler, and Rohner (2009), Nunn and Qian (2014), and Dube and Naidu (2015); for greed, see Reuveny and Maxwell (2001), Grossman and Mendoza (2003), Hodler (2006), and Caselli and Coleman (2013); for state capacity, see Fearon (2005), Besley and Persson (2011), and Bell and Wolford (2015); for capital-intensiveness, see Dal Bó and Dal Bó (2011) and Dube and Vargas (2013); for migration, see Le Billon (2001), Ross (2004), and Humphreys (2005).

${ }^{6}$ A notable exception is Humphreys (2005), who uses among others the distinction between production and reserves to distinguish between different channels, estimating pooled cross-country regressions, as well as Morelli and Rohner (2015) and Dube and Vargas (2013) documenting the role of secession and capital-intensiveness, respectively.

${ }^{7}$ See, e.g., Besley and Reynal-Querol (2014) or Michalopoulos and Papaioannou (2016) for papers using similar grid-cell level data combined with the same conflict data.
} 
during a given year. In this section we provide information about the main datasets and variables used in the paper. More details appear in online Appendix Section A.

Conflict Data.-We use the Armed Conflict Location and Event dataset (Raleigh, Linke, and Dowd 2014), which contains information on the geolocation of conflict events in all African countries. We focus on the 1997-2010 period which overlaps with our mines data. We have information about the date (the precise day most of the time), longitude, and latitude of conflict events within each country. These events are obtained from various sources, including press accounts from regional and local news, humanitarian agencies, or research publications. A first unique feature of ACLED is that it records all political violence, including violence against civilians and rioting and protesting within and outside a civil conflict, without specifying a battle-related deaths threshold. Another is that it contains information on the type of events, their outcome, and the characteristics of the actors on both sides of the conflicts. We know in particular if the event was a battle, the names of the groups involved, and who won the battle. ${ }^{8}$ We shall make use of this information when testing for the channels of transmission. 9

The latitude and longitude associated with each event define a geographical location. ACLED contains information on the precision of the georeferencing of the events. The geoprecision is at least the municipality level in more than 95 percent of the cases, and is even finer (village) for more than 80 percent of the observations. We keep only those events which are geolocalized with the finer precision level for our analysis, and drop duplicated events. 10

The data are aggregated by year and $0.5 \times 0.5$ degree-cell. We construct a dummy variable which equals 1 if at least one conflict occurred in the cell during the year, which we interpret as cell-specific conflict incidence. This is our main dependent variable throughout the paper. Alternatively, we compute a variable containing the number of events observed in the cell during the year, which we label conflict intensity. We also show that our results are robust to modeling cell-specific conflict onset and ending separately.

While the geocoding of the events is cross-checked in the ACLED dataset, it is not immune to potential biases and measurement errors. We cannot rule out the possibility that the reporting of conflicts is biased toward certain types of countries, regions, or events, as some regions might in particular have better media coverage. An event dataset such as ACLED cannot, by definition, be fully exhaustive. Our empirical methodology makes it unlikely however that this characteristic affects our

\footnotetext{
${ }^{8}$ Eight different types of events are included in ACLED: battle with no changes in territory; battle with territory gains for rebels; battle with territory gains for the government; establishment of a headquarters; nonviolent activity by rebels; rioting; violence against civilians; and nonviolent acquisition of territory. Actors are classified according to the following typology: government or mutinous force; rebel force; political militia; ethnic militia; rioters; protesters; civilians; outside/external force (e.g., UN).

${ }^{9}$ The presence of this detailed information and the more exhaustive character of the ACLED are the main reason why we chose to use this dataset, rather than the UCDP-GED dataset. The latter records only deadly events pertaining to conflicts reaching at least 25 battle-related deaths per year, and does not include information on battle event outcomes. We nevertheless also show and discuss the results obtained using the UCDP-GED dataset in online Appendix Section E.

${ }^{10}$ This has no impact when considering conflict incidence, our main variable of interest, but reduces noise when looking at the number of events as we do in a robustness exercise.
} 
results, as structural differences in media coverage or more generally in the reporting of events is captured by cell and country-year fixed effects. ${ }^{11}$

Mines Data.-To each cell-year, we merge information on mines from Raw Material Data (RMD, IntierraRMG). The data contain information on the location of mines around the world since $1980 .{ }^{12}$ For each year, we know whether a mine is active, the year production started, the specific minerals produced, and the total production for each of them. We use these data to identify active mining areas, and the type of minerals they produce. The dataset also includes additional information about the ownership structure and characteristics of the mines, as well as some data about extraction methods. We return to these variables in Sections IIIE and V in which we study the role of minerals' and mining companies' characteristics.

For each cell $k$, we define $M_{k t}$, a dummy variable which equals 1 if a least one active mine is recorded in the cell during year $t$. We identify 25 minerals in our sample of African countries. In the rest of the analysis we focus on the cells producing one or several of the 14 minerals for which we have price data. ${ }^{13}$ We define as the main mineral produced in the cell the mineral with the highest production over the entire period, evaluated at 1997 prices. ${ }^{14}$ Among the 237 mining cells for which a main mineral is identified, 70 percent produce a single mineral, and the main mineral produced represents on average 96 percent of total production value. In the robustness section, we show a number of robustness checks related to the definition of the main mineral; in particular we restrict our sample to single-mineral cells or consider all the minerals produced in a price index instead of the main mineral only.

The RMD dataset collects information mostly for large-scale mines, usually operated by multinationals or the country's government. Hence, small-scale mines, and those that are illegally operated, are not included in our sample. While these measurement errors could lead to some attenuation bias in our estimates, we believe that this concern is limited, given our empirical strategy. First, our baseline specifications include time-invariant versions of $M_{k t}$ and identify the effect of mining through variations in world mineral prices within cells; in other words, measurement errors are unlikely to attenuate our estimates given the inclusion of cell fixed effects. Second, our unit of analysis being an area (i.e., a $0.5 \times 0.5$ degree-cell) where mining takes place, we interpret our variable $M_{k t}$ as a proxy for the extraction area of a given mineral rather than as coding for a specific RMD-referenced mine. If minerals are spatially clustered, these mining areas include all mines, including

\footnotetext{
${ }^{11}$ We also show that our results are obtained across events of different types (battles, riots, violence against civilians). Similarly, when considering jointly ACLED and UCDP-GED events, our coefficient of interest is similar for the two datasets, despite the fact that the UCDP-GED dataset is less exhaustive and records only large, deadly events which are arguably less likely to be affected by reporting bias.

${ }^{12}$ More information is available at http://www.snl.com/Sectors/metalsmining/Default.aspx. Other recent research using the RMD data includes Kotsadam and Tolonen (2016), who study gender and local labor market effects of mining, as well as Knutsen et al. (2017), who assess the impact of mining on local corruption.

${ }^{13}$ These minerals are: Bauxite (aluminum), Coal, Copper, Diamond, Gold, Iron, Lead, Nickel, Platinum (and Palladium/PGMs, i.e., Platinum Group Metals), Phosphate, Silver, Tantalum (Coltan), Tin, and Zinc. These minerals are present in 92 percent of mining cells over our period of study. We do not consider the following minerals: Antimony, Chromite, Cobalt, Lithium, Manganese, Niobium, Rhodium, Tungsten, Uranium, Vanadium, Zirconium.

${ }^{14}$ For some cells, minerals for which we have prices coexist with minerals for which we do not, complicating the identification of the main mineral. In most cases, however, we can identify the main mineral produced by using additional information contained in the RMD data about the name of the mines. More details about the procedure are provided in online Appendix Section A.
} 
small ones. Note that we estimate a number of robustness tests to ensure that our results are not sensitive to changes in the definition of a mining area. In particular, we include the surrounding cells (first and second degrees) or use $1 \times 1$ degree units instead of $0.5 \times 0.5$. As shown later, results are consistent across specifications.

Other Data.--Information on the world prices of the minerals is retrieved from the World Bank Commodities prices dataset. Real prices are measured in constant 2005 US\$. We also add diamond prices from Rapaport. Diamond prices are problematic as these vary significantly according to the quality and type of diamonds produced. There is a large heterogeneity in diamond quality across mines, and the price series for different qualities can move in opposite directions. As the RMD dataset contains no information on diamond quality, we exclude diamonds from our baseline sample in order to limit measurement errors. We show however that our results are robust to the inclusion of this mineral. Similarly we add data on tantalum (coltan) price from the US Geological Survey. Unfortunately this series contains US unit values rather than a world price. To be consistent, we exclude tantalum from our baseline estimations and keep only the minerals for which world price data are available. Again, we show that adding coltan leaves our results largely unchanged. Finally, we add a number of cell-specific variables (distances, climate, ethnic homeland), country-specific data (institutions, social and ethnic cleavages, transparency initiatives), and mineral-specific information (extraction cost or method).

\section{B. Descriptive Statistics}

Our final sample covers 52 countries and 14 minerals (see Appendix Section A for a visual representation of the geolocalization of both conflict events and mines). Only 4 countries display no conflict events over the entire period and there are 20 countries with no active mine recorded. The main minerals present in the dataset are gold (one-third of mining cells), diamond, copper, and coal (around 10-15 percent each). Note that, except in the case of South Africa, the countries contained in our sample typically are small producers of the minerals from a world perspective: the average market share of a country-mineral is around 6.5 percent (the median at 2.9 percent), and drops to 4.5 percent when we exclude South Africa (and the median to 1.6 percent).

Table 1 displays some descriptive statistics. Our sample consists of slightly more than 10,000 cells over 14 years. Several features are worth mentioning. First, the unconditional probability of observing at least one conflict in a given cell and a given year is low, around 6 percent. In the majority of cells no event occurs over the entire period. The probability of observing an active mine in a given cell is also low at 2 percent, but it increases to 9 percent (respectively, 17 percent) when we consider the neighboring cells (respectively, the first- and second-degree neighboring cells). Second, mines tend to be spatially clustered: conditional on observing at least one mine in a given cell, the average number of mines is 2.57 . Finally, the conflict probability is much higher in cells with active mines, around 14 percent. Of course, this could be due to many unobserved cell characteristics, an issue we shall deal with in our estimations. In online Appendix Section B, we document correlations between the presence of mining areas and the likelihood of violent events at the cell 
Table 1-Descriptive Statistics: Cell Level

\begin{tabular}{|c|c|c|c|c|}
\hline & Observations & Mean & Standard deviation & Median \\
\hline \multicolumn{5}{|l|}{$\operatorname{Pr}($ Conflict $>0)$} \\
\hline all cells & 144,690 & 0.06 & 0.23 & 0 \\
\hline if mines $>0$ & 2,798 & 0.14 & 0.35 & 0 \\
\hline if mines $=0$ & 141,892 & 0.05 & 0.22 & 0 \\
\hline battles & 144,690 & 0.03 & 0.17 & 0 \\
\hline viol. against. civ. & 144,690 & 0.03 & 0.17 & 0 \\
\hline riots and protests & 144,690 & 0.02 & 0.12 & 0 \\
\hline \multicolumn{5}{|l|}{ Number of conflicts } \\
\hline all cells & 144,690 & 0.25 & 3.41 & 0 \\
\hline if $>0$ & 7,980 & 4.61 & 13.79 & 2 \\
\hline \multicolumn{5}{|l|}{$\operatorname{Pr}($ Mine $>0)$} \\
\hline only cell & 144,594 & 0.02 & 0.14 & 0 \\
\hline incl. 1st surrounding cells & 144,690 & 0.09 & 0.29 & 0 \\
\hline incl. 1st and 2nd surrounding cells & 144,687 & 0.17 & 0.38 & 0 \\
\hline \multicolumn{5}{|l|}{ Number of mines } \\
\hline all cells & 144,594 & 0.05 & 0.60 & 0 \\
\hline if $>0$ & 2,702 & 2.57 & 3.55 & 1 \\
\hline \multicolumn{5}{|l|}{$\operatorname{Pr}($ number of mines $>2)$} \\
\hline all cells & 144,690 & 0.01 & 0.09 & 0 \\
\hline if mine $>0$ & 2,798 & 0.40 & 0.49 & 0 \\
\hline
\end{tabular}

Source: Authors' computations from ACLED and RMD datasets.

level. We find that the presence of active mines is positively correlated with conflict incidence, both across and within cells.

\section{Exogenous Changes in the Value of Mines: Local Impact}

We turn now to our empirical analysis. First, we discuss our identification strategy and report the baseline results. Second, we provide a series of alternative specifications assessing the robustness of the results. Then we focus on heterogeneous effects. Finally, we perform various quantification exercises.

\section{A. Methodological Issues}

Assessing the causal impact of mining on violence involves a range of methodological challenges. The most obvious relates to the reverse causation from local violence to mine opening/closing. The direction of this bias is negative most likely, i.e., conflict incidence might impact negatively the likelihood of a mine being active. This intuition should work against our finding of a significant positive correlation between mining activity and conflict. However, we cannot rule out the possibility that conflicts affect the value of a mine in a nontrivial way, for instance if the state uses part of the mine production to fight insurgency. ${ }^{15}$

\footnotetext{
${ }^{15}$ Guidolin and La Ferrara (2007) actually find evidence that conflicts increase the value of extractive firms.
} 
In order to address causality, we focus on exogenous variations in the economic value of mines. The idea is that more valuable mines increase local rent-seeking and, consequently, the likelihood of violence. ${ }^{16}$ To abstract from local determinants of violence and guarantee exogeneity, we exploit the variations in the world prices of minerals, and estimate a specification of the following form:

\section{(1) CONFLICT $_{k t}=\alpha_{1} M_{k t}+\alpha_{2} \ln p_{k t}^{W}+\alpha_{3}\left(M_{k t} \times \ln p_{k t}^{W}\right)+\mathbf{F E}_{k}+\mathbf{F E}_{i t}+\varepsilon_{k t}$,}

where $(k, t, i)$ denote respectively cell, time, and country, $\mathbf{F E}_{k}$ are cell fixed effects, and $\mathbf{F E}_{i t}$ is an additional battery of fixed effects that can vary at different levels depending on the specification (e.g., year, country $\times$ year). Note that border cells are assigned to the country that represents the largest share of their area. The dependent variable, CONFLICT $_{k t}$, corresponds to the observation of violent events at the cell-year level where violence is measured in terms of incidence, i.e., a binary variable coding for nonzero events in the ACLED dataset on civil conflicts. Alternative measures of violence are considered in our sensitivity analysis in Section IIIC. The main explanatory variable, $M_{k t}$ is a binary variable coding for the presence of at least one active mine at the cell-year level. The variable $p_{k t}^{W}$ corresponds to the world price in year $t$ of the main mineral produced by the mines present in cell $k$, i.e., the one with the highest total production (evaluated at 1997 prices) over the entire 1997-2010 period. For cells where no active mine ever produces over the period we set $p_{k t}^{W}$ to zero; by contrast, it is nonzero for cells with a mine that is inactive only temporarily. Our sensitivity analysis investigates alternative coding rule for $M_{k t}$ and $p_{k t}^{W}$ (Section IIIC).

In equation (1) we focus primarily on the estimates of $\alpha_{3}$, the coefficient of the interaction term between the price and the dummy for mining activity. This coefficient captures the impact on local violence of an exogenous increase in the world price of a given mineral, in cells where mining extraction of this mineral takes place. ${ }^{17}$ As we include fixed effects at the country-year level, our identification strategy relies on the exogeneity of the interaction term, $M_{k t} \times \ln p_{k t}^{W}$, with respect to the local determinants of conflict. We discuss this identification assumption below.

Exogeneity of Prices.-This seems a reasonable assumption for the world price of minerals, $p_{k t}^{W}$, as mentioned earlier. Still, some mines may be large enough to affect world prices. If conflict occurs in their locations, prices could be affected. Although our sample contains only few countries with potentially large power in the mineral market, we test whether our results are robust to excluding from the sample all cells located in countries belonging to the top ten world producers of a specific mineral (see Section $\mathrm{H}$ in the online Appendix). Another possibility is that time-varying omitted variables could codetermine world prices and local violence in mining areas. The use of country $\times$ year fixed effects in our baseline specifications

\footnotetext{
${ }^{16}$ See Dube and Vargas (2013) for a similar methodology applied to coffee and oil production in Colombia.

${ }^{17}$ An alternative approach would be to focus on price growth over time (i.e., difference in log-prices). Section $\mathrm{M}$ in the online Appendix contains a discussion of these two alternative specifications. We perform unit root tests on the price series and conclude that these are stationary (once purged from their common time trends), which supports the use of price levels in our estimations. Section M also contains several alternative specifications, including dynamic OLS estimations which separate the long-term from the short-term impact of mineral price variations.
} 
alleviates most of this problem, but in our sensitivity analysis we consider placebo exercises to ensure that our results are not driven by comovements of the residual unobserved heterogeneity and world mineral prices.

Endogenous Mining Activity.-As discussed above, potential reverse causation from conflicts to mines opening and closing is an important concern. As a consequence, our coefficient of interest, $\alpha_{3}$, could be partly driven by conflict-induced shifts in the binary variable $M_{k t}$. To account for this issue, we first restrict the estimate of equation (1) to the subsample of cells for which mining activity always takes place during the period (i.e., $V\left(M_{k t}\right)=0$ for a given $k$ ). Given that $M_{k t}=0$ or $M_{k t}=1$ for all years, this variable is now absorbed by the cell fixed effects and the covariates $\ln p_{k t}^{W}$ and $\left(M_{k} \times \ln p_{k t}^{W}\right)$ become identical. Accordingly, we include only the interaction term and the specification takes the following simpler expression:

$$
\operatorname{CONFLICT}_{k t}=\alpha_{3}\left(M_{k} \times \ln p_{k t}^{W}\right)+\mathbf{F E}_{k}+\mathbf{F E}_{i t}+\varepsilon_{k t} .
$$

This specification ensures that our coefficient of interest, $\alpha_{3}$, is identified within cells through the changes in world commodity prices conditional on having permanently active mining activity (i.e., $M_{k t}=1$ for all $t$ ), and not through the potentially endogenous opening/closing of mines.

An alternative way to get rid of endogenous mining activity is to define as mining areas cells where a mine has ever been recorded as active over the 1997 2010 period. ${ }^{18}$ Under this coding rule the mining activity dummy becomes time-invariant, $M_{k} \in\{0,1\}$, such that the econometric specification is given by equation (2) and the coefficient of the interaction term $\alpha_{3}$ keeps on being identified through changes in world mineral prices only. The advantage of this approach is that it can be estimated on the full sample of cells and not on a selected subsample, as is the case with the estimation based on cells without mines opening/closing. Its disadvantage is that a cell can be considered a mining area even when no mining may have taken place in a given year.

Estimation Issues.-Due to the inclusion of several dimensions of fixed effects, we estimate equations (1) and (2) using a Linear Probability Model in our baseline specifications. Nonlinear estimators such as conditional logit or Poisson pseudo-maximum-likelihood estimators are implemented as robustness checks. Note also that with more than 900 country $\times$ year fixed effects in most specifications, estimating the large battery of fixed effects is very demanding from a data perspective. In this respect, keeping in the sample not only cells with mines but also the large number of cells with no mines $\left(M_{k t}=0\right.$ for all $\left.t\right)$ conveys information which is decisive for estimating these dummies. This is why we favor, in our baseline, specifications including the set of cells without mines, coding as zero the world price for these cells. Alternatively, we implement a neighbor-pair fixed effects methodology in the spirit of Acemoglu, García-Jimeno, and Robinson (2012) and Buonanno et. al (2015): equation (2) is estimated on the subsample of mining cells and their immediate

\footnotetext{
${ }^{18}$ In the same vein we consider alternative coding rules in Section IIIC. In particular, we code $M_{k}=1$ if the cell had an active mine in the presample period (i.e., in the five years prior to 1997).
} 
neighboring cells without mines. We define a neighborhood fixed effect that is specific to each (mine + neighbors) group. The price of the main mineral produced in the mining cell is also assigned to its neighbors. By contrast, the mining dummy can differ as it is set to zero in neighboring cells with no mine. Identification hence relies on relative variations in conflict incidence in the mining cell with respect to its neighboring cells when the world price of the main mineral changes. This approach is similar in spirit to a matching estimator. With a sample size reduction by a factor 10 , this is a demanding specification. Its main benefit in our context is that it avoids coding to zero the log of mineral prices in cells with no mines.

Spatial Correlation.-Given the high spatial resolution of the data, it is important to take spatial correlation into account since both conflict and mines are clustered in space. Henceforth, in all specifications standard errors are estimated with a spatial HAC correction allowing for both cross-sectional spatial correlation and location-specific serial correlation, applying the method developed by Conley (1999) and Hsiang, Meng, and Cane (2011). Our treatment is quite demanding, as we impose no constraint on the temporal decay for the Newey-West/Bartlett kernel that weights serial correlation across time periods. The horizon at which serial correlation is assumed to vanish can be infinite (i.e., 100,000 years). In the spatial dimension we retain a radius of $500 \mathrm{~km}$ for the spatial kernel: close to the median internal distance in our sample of African countries according to the CEPII geodist dataset. ${ }^{19}$

\section{B. Baseline Results}

Table 2 reports the baseline results for various sample compositions and definitions of the variables. The dependent variable is conflict incidence. We see that in all columns, the interaction term between world price and local mining activity, our coefficient of interest, is positive and significant at the 1 or 5 percent level. Thus, a spike in mineral prices increases the conflict risk in cells producing these commodities. We estimate equation (1) on the full sample of cells. In column 1, mining activity (mine $>0$ ) is measured with a dummy taking the value 1 if at least 1 mine is active in the cell in year $t$. Cell fixed effects are included with the purpose of controlling for time-invariant codeterminants of violence and mining at the local level—such as weak state capacity and property rights enforcement in remote places or latent political instability (e.g., ethnic cleavages). Country $\times$ year fixed effects also are included to filter out all country-wide time-varying characteristics affecting violence and activity of mines: for example, a war-induced collapse of the central state and property rights.

In column 2, we estimate equation (2) on the subsample of cells without mine opening/closing (i.e., $V\left(M_{k t}\right)=0$ for a given $k$ ). In column 3 we go beyond spatial clustering of standard errors in addressing spatial dependence in the data. To this purpose we allow for spatial lags of our explanatory variable by including the

\footnotetext{
${ }^{19}$ Robustness to alternative spatial and temporal kernels is explored in online Appendix Section F. We have created a new STATA routine based on the one from Hsiang, Meng, and Cane (2011) (ols_spatial_HAC.ado) and its extension to multidimensional fixed effects by Thiemo Fetzer (reg2hdfespatial.ado: itself based on the work of Guimaraes and Portugal 2010). Our routine also enables 2SLS estimations (in samples of limited size given the current STATA limitations).
} 
Table 2-Conflicts and Mineral Prices

\begin{tabular}{|c|c|c|c|c|c|c|}
\hline \multirow{4}{*}{$\begin{array}{l}\text { Estimator } \\
\text { Dependent variable } \\
\text { Sample }\end{array}$} & \multicolumn{6}{|c|}{ LPM } \\
\hline & \multicolumn{6}{|c|}{ Conflict incidence } \\
\hline & All & \multicolumn{2}{|c|}{$V\left(M_{k t}\right)=0$} & \multirow{2}{*}{$\begin{array}{l}\text { All } \\
(4) \\
\end{array}$} & \multicolumn{2}{|c|}{$V\left(M_{k t}\right)=0$} \\
\hline & $(1)$ & $(2)$ & $(3)$ & & $(5)$ & $(6)$ \\
\hline mine $>0$ & $\begin{array}{c}0.112 \\
(0.065)\end{array}$ & & & & & $\begin{array}{c}0.048 \\
(0.065)\end{array}$ \\
\hline ln price main mineral & $\begin{array}{r}-0.029 \\
(0.032)\end{array}$ & & & & & $\begin{array}{c}0.028 \\
(0.019)\end{array}$ \\
\hline ln price $\times$ mines $>0$ & $\begin{array}{c}0.086 \\
(0.034)\end{array}$ & $\begin{array}{c}0.072 \\
(0.020)\end{array}$ & $\begin{array}{c}0.060 \\
(0.021)\end{array}$ & & $\begin{array}{c}0.085 \\
(0.024)\end{array}$ & $\begin{array}{c}0.108 \\
(0.041)\end{array}$ \\
\hline ln price $\times$ mines $>0($ neighboring cells $)$ & & & $\begin{array}{c}0.021 \\
(0.006)\end{array}$ & & & \\
\hline ln price $\times$ mines $>0$ (ever $)$ & & & & $\begin{array}{l}0.045 \\
(0.014)\end{array}$ & & \\
\hline Country $\times$ year fixed effects & Yes & Yes & Yes & Yes & No & No \\
\hline Year fixed effects & No & No & No & No & Yes & Yes \\
\hline Cell fixed effects & Yes & Yes & Yes & Yes & Yes & No \\
\hline Neighborhood fixed effects & No & No & No & No & No & Yes \\
\hline Observations & 143,768 & 142,296 & 127,974 & 143,864 & 142,296 & 17,360 \\
\hline
\end{tabular}

Notes: LPM estimations. Conley (1999) standard errors in parentheses, allowing for spatial correlation within a $500 \mathrm{~km}$ radius and for infinite serial correlation. Variables: mine $>0$ is a dummy taking the value 1 if at least 1 mine is active in the cell in year $t$; mines $>0$ (ever) is a dummy taking the value 1 if at least 1 mine is recorded in the cell at any point over the 1997-2010 period; mines $>0$ (neighboring cells) is a dummy taking the value 1 if at least 1 mine is recorded in neighboring cells of degree 1 and 2 in year $t ; V\left(M_{k t}\right)=0$ means that we consider only cells in which the mine dummy (or dummies in column 3) takes always the same value over the period. Column 6 is estimated on a sample containing only mining cells and their immediate neighboring cells. In columns 1 to 5, ln price main mineral is the world price of the mineral with the highest production over the period (evaluated at 1997 prices) for mining cells, and zero for nonmining cells. In column 6 , ln price main mineral takes the same value for the mining cell and its immediate neighbors. Estimations (1) and (6) include controls for the average level of mineral world price interacted with the mine dummy.

interaction term between mineral price and mining activity in neighboring cells of degrees 1 and 2. ${ }^{20}$ As shown by the coefficient of the second interaction term, we detect an impact on local conflict of mineral price shocks in neighboring cells. The effect is 60 percent lower than for the cell itself (i.e., the first interaction term) confirming that conflict tends to spill over with spatial decay, a feature that is likely to be driven by spatial diffusion of violence (e.g., roaming bands of fighters). ${ }^{21}$ In column 4 we use the alternative definition of mining activity where the mining dummy (mines $>0$ ever) is now equal to 1 for cells where at least one mine has been recorded as active at any point over the 1997-2010 period. The coefficient of interest is slightly lower, an expected feature given that in this specification we define as mining areas places where mining took place in at least one year of the

\footnotetext{
${ }^{20}$ More precisely, we also impose the constraint of no closing/opening mines for neighboring cells. Therefore ln price $\times$ mines $>0$ (neighboring cells) corresponds to the price of the main mineral produced among the neighboring cells with permanent mining activity.

${ }^{21}$ Our favorite interpretation of the results in column 3 is that violence diffuses in space. Henceforth, this specification could be viewed as the reduced form of a TSLS estimate of a variant of equation (2) that would include on the RHS violence in neighboring cells instrumented by price shocks in neighboring cells. We do not want to push this interpretation too far as it could be that spatial dependence is simply driven by measurement errors on the actual surface of mining areas that are constrained by data construction to be contained in a 0.5 degree $\times 0.5$ degree-cell. Technically this additional channel could violate the exclusion restriction of the TSLS.
} 
sample period. This leads to cells with currently inactive mines being treated as mining areas, resulting in potential attenuation bias.

The last two columns deal with alternative sets of fixed effects. Column 5 replicates column 2 without the country $\times$ year fixed effects. Indeed, with 15 percent of the cells belonging to more than one country, the interpretation of the unobserved heterogeneity that is captured by those fixed effects is unclear for border cells. Consequently we use year fixed effects only. In the sensitivity analysis in online Appendix Section L, we explore a more radical approach by dropping border cells. Column 6 implements the neighborhood fixed effects described earlier. We concentrate on the sample of mining cells and their immediate neighbors, and estimate the differential effect of mineral price variations in mining areas compared to their immediate neighbors. Our findings are confirmed; variations in mineral prices have a significantly higher effect in mining cells.

\section{Sensitivity Analysis}

In this subsection we show that the baseline estimates of Table 2 are robust to a large battery of sensitivity checks.

Mining Activity.-We start by investigating the robustness of our results to alternative definitions of mining activity, to ensure further that our results are not driven by endogenous opening/closing of mines (i.e., variations in the mining dummy over time). Tables are relegated to the Appendix.

The first two columns of Appendix Table 8 contain our two baseline ways of dealing with this potential reverse causation issue: considering only cells with a permanently active mine (column 1, the same as column 2 in Table 2), and using a time-invariant dummy for cells containing at least one active mine at any point over the 1997-2010 period (column 2, the same as column 4 in Table 2). In column 3 of Table 8, we use a lagged mine dummy instead of the contemporaneous value. The estimated coefficient remains positive but becomes slightly insignificant. This is not our preferred way of dealing with reverse causality however, as mining activity can be affected by anticipation of future conflicts. In column 4 , the mining variable is coded as 1 from the first year onward when an active mine is observed over the 1997-2010 period, 0 if no active mine was ever recorded, and is coded as missing otherwise. Finally, we use mining activity at the beginning of the period (column 5) or in the presample period ( 5 years in column 6 and entire presample period covered by the RMD data in column 7). Our coefficient of interest is always highly significant and quantitatively stable. ${ }^{22}$

We also inquire robustness to alternative size of the mining area. As discussed in Section II, the RMD dataset does not survey small-scale (potentially illegally operated) mines. Because of spatial clustering of mineral deposits, our main explanatory variable, $M_{k t}$, must be interpreted as a proxy for the extraction area of a given mineral rather than as coding for a specific RMD-referenced mine. But mining areas

\footnotetext{
${ }^{22}$ An alternative way of considering this endogeneity issue is to instrument the mining dummy in the sample period by its presample equivalent. This alternative is explored in online Appendix Section G and Table A.10. Very similar results emerge.
} 
on average could be larger than our cells of a spatial resolution of $0.5 \times 0.5$ degree. Focusing on the impact of mines on the conflict likelihood in its surrounding cell of $0.5 \times 0.5$ degree may underestimate the real impact of being in a mining area. Hence, in Table 9 in the Appendix we broaden the scope of a mining area and we reproduce Table 2 for a grid of cells at a larger resolution ( 1 degree $\times 1$ degree).

Main Mineral and Mineral Prices.-Another important element of our analysis is the way in which we define the main mineral produced in the cell. Note that this has no impact on cells producing a single mineral, which comprise 70 percent of mining cells. For the others, we use the price of the mineral with the highest production over the period, evaluated at 1997 prices. In Table 10 in the Appendix we show that alternative coding choices deliver similar results. We consider our preferred baseline specifications, columns 2 and 4 of Table 2. We keep our baseline definition of the main mineral but restrict the sample, either to mining cells producing a single mineral over the entire period (columns 1-2) or to cells for which the main mineral is the same for each year of the sample (columns 3-4). In columns 5 and 6, we replace the price variable with the average price of all the minerals produced in the cells (for which we have a price), with weights equals to the share of each mineral in total production value over the period.

We also perform a series of consistency checks on mineral prices. In particular, we want to rule out that time-varying omitted variables could codetermine world prices and local violence in mining areas. Indeed, it could be the case that the residual unobserved heterogeneity still comoves with the world prices of minerals despite the wide array of fixed effects we include. We perform a placebo analysis to exclude this last concern and check the validity of our approach. Our idea is to replace the price of the mineral produced in the cell with the price of a mineral that is not produced in the cell. More precisely, we randomly assign a mineral to each of the mining cells and estimate specifications (2) and (4) of Table 2 with this fake $M_{k t} \times \ln p_{k t}^{W}$ variable. We repeat this Monte Carlo procedure in 1,000 draws. Panels A and B of Figure 4 in the Appendix display the sampling distribution of the coefficient of the interaction term for each specification. Reassuringly, the Monte Carlo coefficients are distributed far from their baseline estimates and are massively insignificant. This confirms that our baseline results are not driven by comovements in mineral prices.

Alternative Definitions of Violence.-In all tables we focus on conflict incidence, which reflects our interest in explaining the general presence of conflict. In this section we test for robustness to alternative measures of conflict in terms of intensity, onset, and ending. We first look at intensity of violence as measured by the yearly number of ACLED events reported in a given cell. The results are displayed in Appendix Table 11, where columns 2 and 4 of the baseline Table 2 are replicated in panels $\mathrm{A}$ and $\mathrm{B}$, respectively. For each panel, column 1 reports the LPM estimation results for the full sample. The distribution of the number of events being right-skewed due to overreporting of intense events in ACLED, ${ }^{23}$ we

\footnotetext{
${ }^{23}$ Take for example the following event: "CNDD rebels attacked Kazirabageni in Makamba Province. They clashed with security forces and 15 people were killed." It takes place from April 17-22, 2002 and each day is coded as a separate event in ACLED.
} 
deal with outliers by winsorizing at top 5 percent in column 2 and at 2 SD above the mean in column 3. We redo the same exercises in columns 4-6 with a Poisson pseudo-maximum likelihood estimator - a well-adapted procedure for count data. The results are again better estimated when extreme values are treated. This feature suggests that mineral prices impact violence intensity in a nonlinear (concave) way. We investigate further this interpretation in the last two columns by estimating a LPM on the full sample with a $\log (1+x)$ transformation of the LHS variable (column 7) and an inverse hyperbolic sine transformation (column 8). Finally we study cell-specific onsets and endings of conflict separately in Section D of the online Appendix, and in particular in Tables A.6 and A.7. Note that this exercise has a limited scope in the context of our spatial microdata where, at the cell level, the vast majority of events is short lived. ${ }^{24}$ Finally, we complement our sensitivity analysis on violence measurement by using an alternative conflict database with geocoded information, namely the Conflict Data Program Georeferenced Events Dataset (UCDP-GED). The UCDP-GED focuses on deadly incidents associated with civil wars, as identified by the UCDP-PRIO Armed Conflict Database. All these results are displayed and discussed in Section E of the online Appendix.

Other Robustness Checks. - We perform various additional sensitivity checks that are discussed in details in the online Appendix. For the sake of brevity we simply list them here: (i) we investigate alternative spatial and temporal kernels in the computation of standard errors (Section F); (ii) we instrument world prices $\times$ actual mines, using world prices $\times$ historical mines as instrument (Section $G$ ); (iii) we remove from the estimation sample all cells located in a top-10 world producer of the main mineral produced in the cell (i.e., countries that could have some influence on world prices) (Section $\mathrm{H}$ ); (iv) we show that our results are robust to the inclusion of diamond and coltan (tantalum) mines in the sample, and that they are not driven by any specific mineral, by excluding sequentially each mineral from the sample (Section I); (v) we use a nonlinear (logit) fixed effects estimator instead of a LPM (Section J); (vi) we use, instead of our binary mining variable, the number of mines or total production of the main mineral as measures of the intensity of mining activity in the cell (Section K); (vii) border cells are removed from the sample to ease the interpretation of the country $\times$ year fixed effects (Section L); (viii) we consider price shocks in log differences rather than in levels (Section M); (ix) we include time-varying climate variables (rainfall and temperature) which might be correlated with commodity price variations (Section $\mathrm{N})$; (x) we test for nonclassical measurement errors affecting our mining data points following the approach by König et al. (forthcoming) (Section $\mathrm{O}$ ).

\footnotetext{
${ }^{24}$ Indeed the potential issue with using conflict incidence as a dependent variable has been raised by the macro-level literature. Conflict being a persistent variable, one should estimate a dynamic model with the lagged conflict variable included on the right-hand side, or equivalently, model onset and ending separately (Bazzi and Blattman 2014). The problem is less clear in our case as local conflict incidence is much less persistent than country-specific incidence.
} 


\section{Country Characteristics and Mining-Induced Violence}

Is the abundance of valuable mines always a curse for political stability? Minerals could exacerbate instability in countries where the conflict risk already is latently present due to social cleavages or weak institutions. Minerals may not necessarily be the root cause of conflicts, but they could facilitate them, a mechanism we investigate in detail in the second part of the paper. In this subsection we consider how country characteristics may modify the average effect of mineral price variations on local conflicts.

Inequality and Diversity: How Does the Social Fabric Matter?-Social cleavages are considered in the literature as important sources of grievances and conflicts. A natural question is to assess whether these also amplify mining-induced violence. ${ }^{25}$ We consider a battery of indicators of social cleavages at the country and cell levels. Starting from our preferred specifications (columns 2 and 4 of Table 2), we include triple interactions between our main explanatory variable $\left(M_{k} \times \ln p_{k t}^{W}\right)$ and the indicators of social cleavages. Table 12 in the Appendix displays the results. We focus on: (i) the Gini index of gross income distribution (Solt 2014); (ii) ethnic and religious fractionalization or polarization (Reynal-Querol 2014); and (iii) the presence of indigenous group in the cell. ${ }^{26}$ The only variables which enter with statistically significant coefficients are indicators of religious fractionalization or polarization. The results suggest that mining shocks have the strongest conflict-inducing effects in religiously divided places. ${ }^{27}$ Note that this finding holds when we include fractionalization and polarization variables simultaneously.

Domestic Institutions: Can Good Governance Stop the Guns?-While natural resources often have been thought of as affecting the nature and quality of institutions, relatively little attention has been paid to the impact of the interaction between institutional quality and natural resource abundance on political stability and prosperity. ${ }^{28}$ There are, however, reasons to expect natural resource extraction to have a stronger impact in weak states. It might be easier for local armed groups to extract rents from mining areas in such countries.

We follow the same methodology as in Table 12 to estimate the coefficients of the triple interactions between our main explanatory variable and indexes of institutional quality $\mathrm{IQ}_{i}$ : a binary variable equal to 1 when a country's presample (1996)

\footnotetext{
${ }^{25}$ There is a small literature finding that the resource curse is most present in ethnically fractionalized countries (see, e.g., Hodler 2006).

${ }^{26}$ We build the binary variable InDIGENOUs that takes a value of 1 if all groups in a given cell are indigenous. By contrast, InDIGENOUs takes a value of 0 if there is at least one non-indigenous group in the cell. For the sake of statistical analysis we prefer this coding rule to the alternative option of coding for indigenous presence (i.e., at least one indigenous group in the cell) because in quasi all cells there is at least one indigenous group. The list of ethnic groups and information on their location is from Cederman, Buhaug, and Rød (2009). Drawing on a variety of sources, we have coded for each ethnic group whether it is INDIGENOUs in a given country (i.e., settled in a place for several centuries).

${ }^{27}$ In our sample, the five most religiously divided countries in terms of ethnic polarization are Ethiopia, Botswana, Togo, Zambia, and Zimbabwe (in terms of fractionalization, Ghana and Côte d'Ivoire replace the last two countries).

${ }^{28}$ See Mehlum, Moene, and Torvik (2006) and Andersen and Aslaksen (2008).
} 
institutional score is above the sample median. ${ }^{29}$ All variables used are described in online Appendix Section A. Appendix Table 13 displays the results. We use (i) a standard and synthetic measure of institutional quality at country-level (International Country Risk Guide); (ii) four more specific indicators of institutional quality: government effectiveness, rule of law, voice and accountability, and control of corruption; $;{ }^{30}$ and (iii) the standard democracy score of Polity IV. The coefficient of the triple interaction with Voice and Accountability is positive in both columns, but statistically significant only in column 3. Further, the coefficient of the triple interaction with control of corruption in both columns is negative, and statistically significant in column 4 , indicating that the impact of mining price spikes on conflict may be lower in countries with stronger anti-corruption measures.

In a nutshell, we do not detect big heterogeneous effects for different institutional arrangements. Note that our country-level institutional measures are crude proxies, and our results may suffer from attenuation bias. Indeed, the last section of our paper shows that anti-corruption and transparency measures have a significant impact on specific types of events and mining companies. ${ }^{31}$

\section{E. Mineral Characteristics}

We now study whether our results generalize to all types of minerals or if some subgroup of minerals, with specific characteristics are particularly conflict-prone.

Labor-versus Capital-Intensiveness.-The labor- versus capital-intensiveness of a given commodity has been linked to conflict in the literature. In a generalequilibrium framework where (labor-intensive) appropriative activities compete for recruiting manpower with labor-intensive production, it has been shown that only a price spike in the capital-intensive sectors fuels conflict, while higher prices in labor-intensive sectors do not jeopardize peace (Dal Bó and Dal Bó 2011). Dube and Vargas (2013) provide empirical evidence in line with this reasoning, comparing the effect of commodities price variations in coffee-abundant versus oil-abundant municipalities in Colombia.

To investigate this question, we have built a number of mineral-specific proxies of capital-intensiveness (see data description in online Appendix Section A). It turns out that capital-intensiveness is difficult to measure because of the high within-mineral diversity in production methods and types of mines and opaque communication of commodity firms. Note also that our exercise has limited comparability with Dube and Vargas (2013) because variation in capital-intensiveness between coffee and oil production is huge, while in our case cross-mineral variations in capital-intensiveness are modest.

\footnotetext{
${ }^{29}$ We use presample scores to mitigate endogeneity concerns. We focus on the year 1996 as many of the institutional variables are not available for earlier years.

${ }^{30}$ We make use of the Worldwide Governance Indicators dataset from Kaufmann, Kraay, and Mastruzzi (2013). The indicators of this dataset are based on a great number of individual variables from 32 data sources. These four individual measures are mapped into clusters of key dimensions of government quality, with higher scores indicating better governance.

${ }^{31}$ The type of corruption may also matter: In Section $\mathrm{P}$ of the online Appendix we study how corruption at the port affects the impact of mineral prices variations on conflict. We find stronger evidence of a conflict-inducing effect of our proxy of port-level corruption.
} 
We consider three different proxies of capital-intensiveness using data from RMD. For a given metal, OPEN CAST is defined as the average percentage of mines in Africa that use, at least for part of their extraction, the open-cast (respectively, open-pit) mining method. Open-cast is often argued to be a particularly capitalintense mining method. ${ }^{32}$ The second proxy, ENERGY INTENSITY, corresponds to the ratio of $\ln ($ Energy/Production) over $\ln ($ Employees/Production). The third proxy, MINE AGE, is the number of years since mining activity started in a given cell with the assumption that older mines on average should be relatively less capital-intensive. Obviously mine age is a crude proxy of capital-intensiveness and it may also correlate with other factors, such as, e.g., environmental grievances of local stakeholders. Results are shown in Table 14 in the Appendix. We focus on the triple interaction term between our main explanatory variable $\left(M_{k} \times \ln p_{k t}^{W}\right)$ and each proxy of capital-intensiveness. None of these coefficients is statistically significant. A possible interpretation is that all our minerals are capital-intensive in absolute terms, and that they are not different enough in terms of technology to have detectable heterogeneous effects on conflicts. ${ }^{33}$

Rents, Lootability, and Bulkiness.-The literature has argued that more precious commodities generating larger rents are more conducive to fighting. Larger rents do not only increase the prize to be appropriated by the winner, but also constitute attractive opportunities for appropriation and looting during the conflict, helping rebel groups to fund their activities. What also matters besides the value of a resource is the relative ease with which it can be extracted. Resources that are easier to find, that can be exploited using artisanal tools, and that are easier to transport are more lootable, i.e., easier for rebels to appropriate. Further, the recent paper by Sanchez de la Sierra (2015) makes the point that bulky commodities lead violent actors to impose monopolies of violence and sustain taxation. Bulkiness seems to have several countervailing effects as far as conflict is concerned. Bulky metals usually are very diluted in the stone, which is why they are often expensive, and hence an attractive loot. At the same time, they are harder to extract and transport, on the one hand lowering their attractiveness for looting, but on the other hand making it potentially easier to engage in extortion of local producers.

We consider three different proxies by which to study how minerals' value, lootability, and bulkiness may affect the nexus between price spikes and fighting (see Table 15 in the Appendix and Section A in the online Appendix for data information). First, we split the set of minerals into high versus low value-to-weight minerals. We interact our main explanatory variable with two mutually exclusive dummies coding for minerals with a 1997 price (in US\$ per ton) above or below the sample median.

\footnotetext{
${ }^{32}$ Open-cast is often argued to be less labor-intensive than underground mining: "Underground methods from deep deposits (which) are generally more labor-intensive and expensive to mine than deposits mined by open-pit methods." (ILO 1990, p. 18)

${ }^{33}$ We have also looked at the following additional proxies of capital-intensiveness: alternative measures of open-cast mining (average percentage of mines using open-cast technologies for a given mineral computed at the country, or cell level); alternative measure of open-cast mining using alternative data from Hargreaves and Fromson (1983); production-function-based estimates of capital-intensiveness; measures of average lead time to set up a mining site; share of artisan production for particular minerals (which is also related to the lootability of a given mineral, as discussed below). All of those proxies delivered similar results with a coefficient of the triple interaction that is nonsignificantly different from zero. Section $\mathrm{Q}$ in the online Appendix provides the results for some of these variables.
} 
We find that the coefficient of interest is equal to 0.046 for minerals BELOW MEDIAN PRICE, while for minerals ABOVE MEDIAN PRICE the analogous coefficient is almost twice as large (column 1). A similar picture emerges in column 2. This suggests that price spikes of more precious metals have a stronger conflict-inducing effectconsistent with recent evidence on mineral discoveries from Smits et. al (2016). Second, we interact the mining price shock with a dummy variable HIGH RENTS that corresponds to the mineral-specific ratio of price over cost for all African mines being above the sample median. The coefficient of the triple interaction is nonsignificant (columns 3 and 4). Last, we interact our price shock variable with a measure of average metal concentration in its corresponding ore (i.e., the ore grade). As pointed out above, bulky metals like platinum usually are very diluted in the stone and often expensive, while cheaper ones like iron have a larger ore grade. ${ }^{34} \mathrm{We}$ find that the coefficient of the triple interaction is negative and significant (columns 5 and 6), suggesting that bulky/diluted metals entail a larger conflict risk when prices spike. This could be driven by the fact that they are more valuable, increasing the potential for looting. Moreover, mining companies extracting bulky minerals also have a hard time hiding production, making it easier for armed groups to control the mining site and engage in extortion.

\section{F. The Nature of Mining-Induced Violence}

From the Wild West to South Africa, mining areas are storied for danger and lawlessness. They attract young and uneducated males; labor regulation is often lenient, not to say absent; property rights enforcement is a challenge, and this weak institutional environment makes them particularly crime-prone (see Couttenier, Grosjean, and Sangnier forthcoming for statistical evidence on homicide rates in US mining areas). By nature, violence, rooted in riots and protests, is likely to be spatially concentrated around mining areas. By contrast, battles between fighting groups over the control of mines can spread to other areas as appropriation relaxes the financing constraints of future fighting capacity. Uncovering the nature of mining-induced violence is thus crucial for understanding whether it can escalate from the local to the global level. Here we provide evidence that different types of events (in terms of scale and objectives) are affected by changes in mineral prices.

In Table 3 we replicate our baseline specifications (columns 2 and 4 of Table 2) for each of the three categories of violent events covered by the ACLED dataset: battles between fighting groups, violence against civilians, and riots/protests. As expected, we find that an increase in mineral prices leads to more riots/protests (columns 5 and 6) and more violence against civilians (columns 3 and 4). More important, however, the occurrence of battles is also significantly affected by changes in the value of mines, as shown in column 1, confirming that the appropriation of mines is a key driver of violence. ${ }^{35}$ In the specification of column 2 , the coefficient of battles now

\footnotetext{
${ }^{34}$ It is important to keep in mind that we focus here on large-scale industrial mining production. Some precious, very diluted metals like gold may be bulky in industrial production yet much less bulky when extracted in artisan, alluvial depletion.

${ }^{35}$ The size of the coefficients is smaller here than in our baseline results, reflecting the fact that the unconditional probability of observing specific types of events is smaller than the probability of observing any type of event, as shown in Table 1.
} 
Table 3-Minerals Price and Types of Conflict Events

\begin{tabular}{|c|c|c|c|c|c|c|}
\hline \multirow{3}{*}{$\begin{array}{l}\text { Conflict incidence var. } \\
\text { Sample }\end{array}$} & \multicolumn{6}{|c|}{ LPM } \\
\hline & \multicolumn{2}{|c|}{ Battles } & \multicolumn{2}{|c|}{ Violence against civ. } & \multicolumn{2}{|c|}{ Riots/protests } \\
\hline & $\begin{array}{c}V\left(M_{k t}\right)=0 \\
(1)\end{array}$ & $\begin{array}{l}\text { All } \\
(2)\end{array}$ & $\begin{array}{c}V\left(M_{k t}\right)=0 \\
(3)\end{array}$ & $\begin{array}{l}\text { All } \\
(4)\end{array}$ & $\begin{array}{c}V\left(M_{k t}\right)=0 \\
(5)\end{array}$ & $\begin{array}{l}\text { All } \\
(6)\end{array}$ \\
\hline ln price $\times$ mines $>0$ & $\begin{array}{c}0.016 \\
(0.008)\end{array}$ & & $\begin{array}{c}0.040 \\
(0.014)\end{array}$ & & $\begin{array}{c}0.044 \\
(0.018)\end{array}$ & \\
\hline ln price $\times$ mines $>0($ ever $)$ & & $\begin{array}{c}0.002 \\
(0.006)\end{array}$ & & $\begin{array}{c}0.034 \\
(0.010)\end{array}$ & & $\begin{array}{c}0.038 \\
(0.011)\end{array}$ \\
\hline Country $\times$ year fixed effects & Yes & Yes & Yes & Yes & Yes & Yes \\
\hline Cell fixed effects & Yes & Yes & Yes & Yes & Yes & Yes \\
\hline Observations & 142,296 & 143,864 & 142,296 & 143,864 & 142,296 & 143,864 \\
\hline
\end{tabular}

Notes: LPM estimations. Conley (1999) standard errors in parentheses, allowing for spatial correlation within a $500 \mathrm{~km}$ radius and for infinite serial correlation. Variables: mines $>0$ is a dummy taking the value 1 if at least 1 mine is active in the cell in year $t$; mines $>0$ (ever) is a dummy taking the value 1 if at least 1 mine is recorded in the cell at any point over the 1997-2010 period; $V\left(M_{k t}\right)=0$ means that we consider only cells in which the mine dummy takes always the same value over the period; In price main mineral is the world price of the mineral with the highest production over the period (evaluated at 1997 prices) for mining cells, and zero for nonmining cells.

loses statistical significance. In Section T of the online Appendix, we display the full set of results by replicating, for each category of violent events, all specifications of the baseline Table 2. As shown in Table A.26 for battles, with the exception of column 4, the coefficient of interest is positive and statistically significant throughout in all columns. Similarly, Tables A.27 and A.28 replicate the baseline Table 2 for violence against civilians and for riots, respectively. In both tables the coefficient of interest is statistically significant in 5 out of 6 columns.

\section{G. Quantification}

How large is the effect of mineral price variations on the probability of conflict? Taking the baseline specification of Table 2, column 2, a one-standard-deviation increase in the price of all minerals from their mean translates into an increase in this probability from 0.169 to 0.225 . This is of sizable magnitude, but concerns only the cells where active mining takes place. When we also consider the surrounding cells (Table 2, column 3), conflict probability rises from 0.197 to $0.253 .{ }^{36}$

Over the period of our study, mineral prices more than doubled on average. ${ }^{37}$ For instance, in constant 2005 US\$, an ounce of gold was valued at \$338 in 1997, and reached $\$ 1,084$ in 2010. This spectacular rise of mineral prices over the 20002009 period, known as the 2000s commodity boom or commodities super-cycle, has attracted quite a lot of attention. There is a consensus among scholars that no

\footnotetext{
${ }^{36}$ These numbers imply an increase in conflict probability of around 30 percent for a standard deviation increase in price (i.e., a $0.78 \mathrm{log}$ point increase). Interestingly, these magnitudes are quite close in absolute terms to the (conflict-reducing) effect of agricultural commodities shocks found by the literature. For instance, Dube and Vargas (2013) find that a 68 percent fall in coffee prices in the average Colombian coffee-producing municipality results in a 14 to 31 percent increase in conflicts, depending on the conflict measure. Our point estimates are also similar in magnitude to the effect found using ACLED data by Berman and Couttenier (2015), who study how changes in foreign demand for agricultural commodities produced by sub-Saharan African region affect violence.

${ }^{37}$ Prices have been multiplied by 2.8 in constant US\$. Figure A.4 in online Appendix Section A shows the evolution of the price of each of the minerals.
} 
contraction of resource supply is to blame, but rather a rapid and substantial increase in demand, particularly so from the BRICS countries. As pointed out by Carter, Rausser, and Smith (2011, p. 107), "strong global demand, especially in lowermiddle-income countries" helped set the stage for this commodity price boom, and "this strong demand was reflected in low real interest rates, a declining US dollar, and strong GDP growth, and it contributed to the reduction in inventory levels that made commodity markets vulnerable to supply and demand shocks." Similarly, Humphreys (2010, p. 1) points out that the great metals boom between 2003 and 2008 "can be readily explained by the unusual strength of the demand shock and the lagged response of the supplying industry, with prices receiving an additional boost from the activities of commodity investors."

What has been the effect of the commodity super-cycle on conflicts in Africa? In Figure 1, we compute, for each country with recorded mines, the contribution to the observed violence of this historical rise in mineral prices (see Figures A.7 and A.8 in the online Appendix for the map equivalent). The quantification being related to the number of conflict events, our exercise (panel A) is based on the PPML estimates from Table 11. Nevertheless, we also include the quantification based on LPM estimates from Table 11 for the sake of robustness (panel B). ${ }^{38}$ In both cases the effect is highly heterogeneous across countries. Averaging across all countries with at least one recorded mine, we find that the historical rise in mineral prices contributed on average to 24 percent of the observed country-level violence using PPML estimates (14 percent using LPM). As is apparent in Figure 1, this number is however inflated by countries such as Mauritania, in which only a few conflict events are recorded (see online Appendix A.3). ${ }^{39}$ Effects on average are larger when computations are based on the sample with permanently active mines (see Table A.9 in the online Appendix).

We have several reasons to believe that these numbers are conservative estimates. First, our dataset is not exhaustive. Only two percent of the cells contain active mines; we consider surrounding cells as well, but many small-scale mines are not included, although they may have a significant impact on violence, contributing to the one we identify here. Further, not all minerals are taken into account in these

\footnotetext{
${ }^{38}$ More precisely, we compute the counterfactual share of events that would not have happened if prices had stayed stable across the entire period. The PPML estimator is our preferred one given the nature of the data. However, we cannot include country $\times$ year in these estimations. For this reason we complement these results with LPM estimates because LPM allows the inclusion of two large sets of fixed effects. In both cases, we use as baseline sample B of Table 11 (i.e., define mining areas as cells in which a mine was active at some point), which allows keeping all cells in the sample and taking into account the effect of mineral price variations in both mining cells and their neighbors. Here is the detail of our quantification procedure: (Step 1) We estimate specifications similar to columns 5 and 2 of Table 11 where we add the price of the main mineral in neighboring cells of degree 1 and 2; (Step 2) we compare for each year and cell the predicted number of events for the observed prices with the counterfactual prediction when prices are set at their 1997 level; (Step 3) we sum events across cells and years for each country; (Step 4) we take the ratio of these counterfactual prevented events over the total number of events observed in the country during the 1998-2010 period.

Figures A.5 and A.6 in the online Appendix show, by cell, the predicted decrease in the conflict probability that would be observed in 2010 if the prices were the same as in 1997. When aggregated at the country level as in Figure 1, the magnitude of the effect obviously varies with the number of mining areas in the country.

${ }^{39}$ When we adopt a more conservative approach and consider only countries with more than 50 events observed over the period, we find that the observed rise in mineral prices contributed to a 16 percent of the observed violence (8 percent in LPM estimations). Alternatively we can aggregate violence at the continental level. In that case the contribution of mineral prices to violence ranges from 7.7 percent in PPML estimations to 3.5 percent in LPM estimations, reflecting the fact that increases in prices have a relatively small effect on the countries in which the lion's share of conflict events are recorded (Angola, Democratic Republic of Congo).
} 
Panel A. PPML

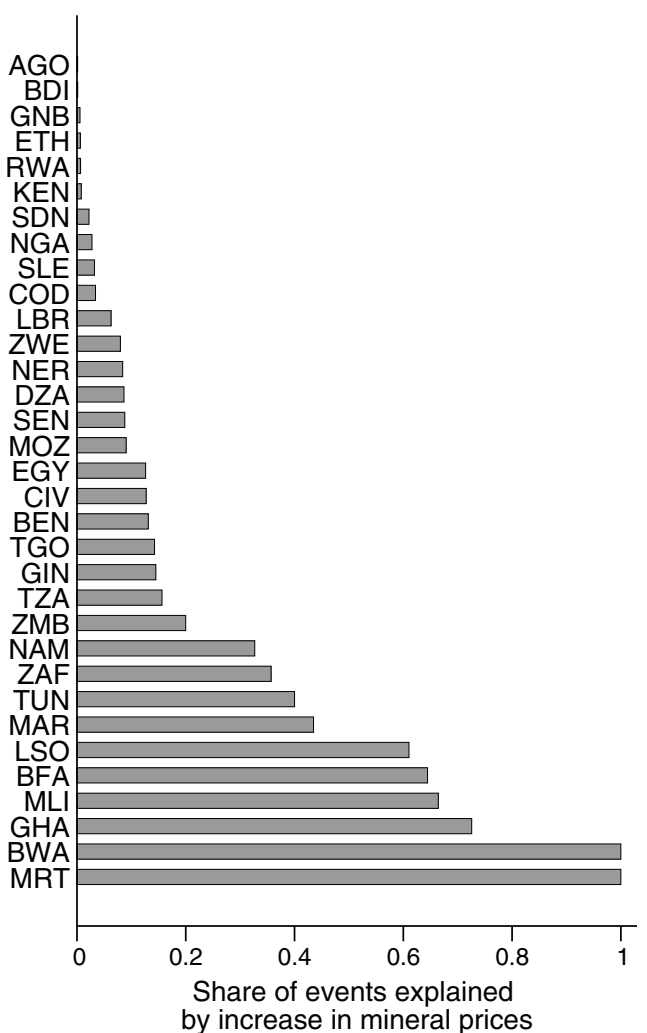

Panel B. LPM

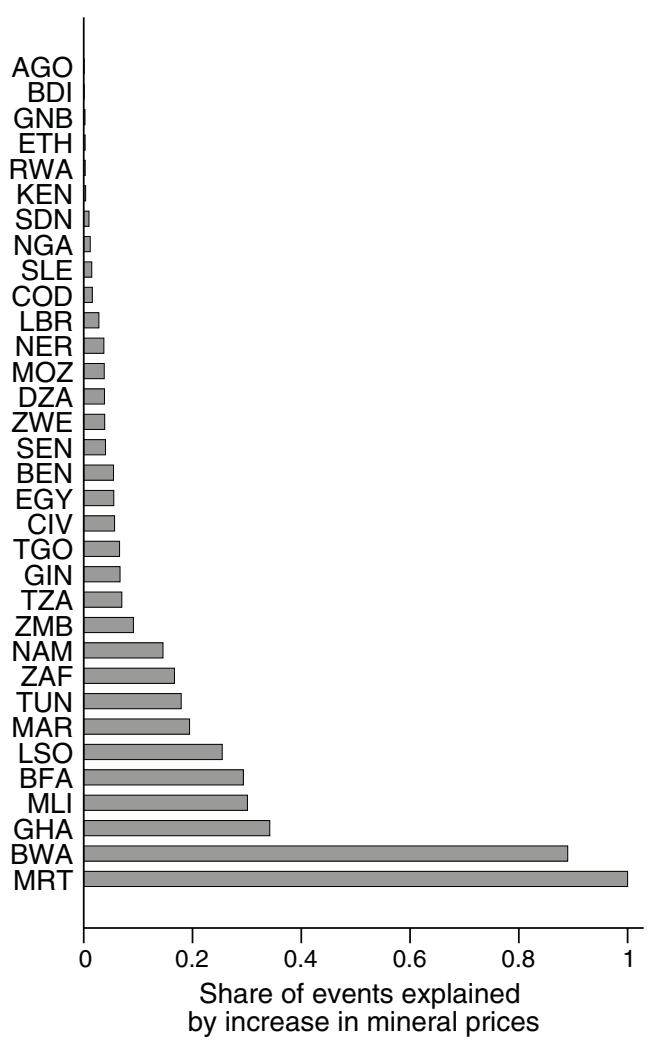

Figure 1. The Contribution of Rising Mineral Prices to Violence in Africa

Notes: These figures represent for each country the counterfactual share of events that would not have happened if prices had stayed stable at their 1997 level across the entire period. Predictions are based on an estimation similar to Table 11, panel B, column 5 and 2, except that we also include the interaction term between mineral prices and the mining dummy for neighboring cells.

estimations. Second, and more important, so far our results only deal with the local and contemporaneous impact of mining on violence. In the next section, we emphasize how mining can diffuse violence over space and time, by improving the financial means of armed groups.

\section{Feasibility and the Diffusion of Violence}

So far our empirical analysis has focused on local violence, i.e., in the immediate surroundings of mining areas. As mentioned in the introduction, several mechanisms may be at play to explain our findings: rebel finance/feasibility; greed/ rent-seeking and secessionism; weak state capacity and extractive institutions; grievances; or migration/population changes. 40 In this section and in Section V, we

\footnotetext{
${ }^{40}$ The opportunity cost channel-spikes in mineral prices generate increases in income and in the opportunity cost of rebellion-would go in the direction opposite to our findings. Section S in the online Appendix specifically considers the migration channel. More precisely, we try to determine whether our results are driven by population
} 
focus specifically on the feasibility channel, and provide various pieces of evidence suggesting that it is empirically relevant. The main objective of this section is to test for this mechanism by exploiting the various dimensions of our data-time-series, geolocation, information on the outcome of the violent events, their type, and the identity of the perpetrators.

The main empirical challenge consists of retrieving information on the effective presence and influence of groups in mining territories. We follow two approaches. First, we assume that rebel groups benefit relatively more from the extractive rents of mines that are located in their ethnic homeland. If mining cash impacts the conflict risk partly through the mechanism of increased feasibility of financing rebellion, we expect rebel groups with more resource-rich homelands to thrive. This analysis has the statistical virtue of leading to a relatively large sample of mine-group combinations. Still, the match between ethnic affiliation and effective control of mining rents may not always be fully accurate, as some groups operate far beyond their group homelands.

Hence, we also take a second approach using unique ACLED information on battle-induced territorial changes in areas with or without mines. This is a more precise approach than the first one, but is based on a relatively small number of events. This second approach focuses on the diffusion over space and time of mininginduced violence, assessing whether mining activity is a factor of escalation from local violence to large-scale conflict. Of course, the feasibility of financing rebellion channel we wish to assess does not require that rebel groups fight elsewhere, i.e., spatial diffusion is not that a necessary condition for the presence of the feasibility channel. Still, the patterns of diffusion we observe are consistent with this channel, and difficult to explain by other channels alone. Thus, studying diffusion is not only interesting in itself, but provides additional suggestive evidence consistent with the view that mineral rents finance rebellions, i.e., make rebel movements easier to set up and sustain over time and space, or, put differently, make conflict feasible. The logic is that rebel groups, by controlling mining areas, can step up their military capacity and scale up their operations. This can result in spatial diffusion and escalation of the conflict. Rebel groups do not need to operate the mines themselves; they can also extract rents from mining areas through bribing/extortion, as discussed earlier.

In the following, we extend our dataset in a new dimension, namely the fighting group operating in each grid cell. We restrict our analysis to the 148 rebel groups that are active in our sample period, ignoring other types of fighting groups. ACLED considers as rebel groups "political organizations whose goal is to counter an established national governing regime by violent acts." We do not consider smaller groups (e.g., political militias and communal militias) because they are more local, and contrary to rebel groups, their objective is not to replace or change the political regime in power. ${ }^{41}$

changes/migration into mining areas caused by increases in prices. We fail to find significant effects of our mining price shocks on local population or nighttime lights. Similarly, the effect of mining prices on conflicts is not larger in cells located close to the capital city which have lower migration costs.

${ }^{41}$ This is the distinction that ACLED makes between these groups and rebel groups: "militia activity is orientated toward altering political power to the benefit of their patrons within the confines of current regimes, whereas the goal of a rebel group is the replacement of a regime." 


\section{A. Mines Located in Ethnic Homelands}

We first test whether positive price shocks on the minerals extracted in the ethnic homeland of a rebel group boost its fighting operations. Exploiting ACLED information on the identity of the rebel groups, we assign to each group a main ethnic affiliation, based on the ethnicity of the group's leaders and troops. Of the 148 rebel groups in our sample, we are able to identify the presence or the absence of an ethnic affiliation for 109 groups (74 percent); the remaining groups are dropped from the analysis. ${ }^{42}$ Then we use the geocoordinates of ethnic homelands from the Georeferencing of Ethnic Groups (GREG) dataset (Weidmann, Rod, and Cederman 2010) to build the number of mines and main minerals produced in the ethnic homeland of each armed group at the beginning of the sample period. ${ }^{43}$ We use a balanced dataset containing, for each rebel group, all combinations of countries $\times$ years where the group potentially can be active. Here we allow each rebel group to be potentially present in all the countries in which it has been involved in at least one event over the period. ${ }^{44}$ Therefore, our unit of analysis is a rebel group $\times$ country of operation $\times$ year triplet $(g, i, t)$. Table A.32 in the online Appendix contains some descriptive statistics on the sample used in this section. The unconditional probability of conflict incidence- 0.21 - is logically higher than at the cell level. Conflict is also more likely within the boundaries of the rebel group's homeland, and in ethnic homelands containing mining areas.

We now study how conflict incidence at the rebel group-country level is affected by mineral prices in the ethnic homeland of the group, and we estimate the following specification:

$$
\text { CONFLICT }_{g i t}=\beta_{1} \ln p_{g t}^{W}+\beta_{2} \ln p_{g t}^{W} \times M_{g}+\mathbf{F E}_{g i}+\mathbf{F E}_{i t}+\varepsilon_{g t},
$$

where CONFLICT $_{\text {git }}$ is a dummy coding for the incidence of a conflict involving group $g$ in country of operation $i$ during year $t$. The variable $\ln p_{g t}^{W}$ is the world price of the main mineral produced by mines located in the homeland of the main ethnicity of rebel group $g$ (the mineral observed in the largest number of cells; robustness results using the prices of all minerals aggregated into a price index are discussed below) and $M_{g}$ is the number of mines producing this mineral in the homeland at the beginning of the period. The coefficient of interest, $\beta_{2}$, is a proxy for the mining-related financial capacity of the group. We expect it to have a positive sign, as better-funded groups are able to extend their fighting operations. Note that this is a somewhat imprecise proxy for effective control of the mining rents — and subject to

\footnotetext{
${ }^{42}$ Examples of matches are: Lord's Resistance Army, that is linked to the Acholi ethnic group; National Movement for the Liberation of Azawad, that is composed of Tuaregs; and Ogaden National Liberation Front, that is associated to the Somali ethnic group.

${ }^{43}$ GREG includes the geographical location of all ethnic groups, based on the widely used Soviet Atlas Narodov Mira from 1964. While this atlas has the downside of being dated, it has the advantage of addressing concerns of reversed causation that would arise if we were to use current ethnic group homelands (i.e., our dependent variables, conflict in the year 2000, could affect current group location). Note that the main competing dataset, GeoEPR, suffers from the fact that it includes only ethnic groups that are judged as politically relevant, which could result in a selected sample.

${ }^{44}$ For instance, the Lord's Resistance Army is assumed to be potentially operating in all cells of Central African Republic, DRC, Sudan, and Uganda.
} 
Table 4-Feasibility: Mines in Ethnic Homelands

\begin{tabular}{|c|c|c|c|c|c|c|}
\hline \multirow{4}{*}{$\begin{array}{l}\text { Estimator } \\
\text { Dependent variable } \\
\text { Conflict zone }\end{array}$} & \multicolumn{6}{|c|}{ LPM } \\
\hline & \multicolumn{6}{|c|}{ Conflict incidence } \\
\hline & \multicolumn{2}{|c|}{ Unrestricted } & \multicolumn{2}{|c|}{ Outside ethnic homelands } & \multirow{2}{*}{$\frac{\text { Unrestr. }}{(5)}$} & \multirow{2}{*}{$\begin{array}{c}\begin{array}{c}\text { Outside } \\
\text { ethn. homel }\end{array} \\
(6)\end{array}$} \\
\hline & (1) & (2) & (3) & (4) & & \\
\hline \multicolumn{7}{|l|}{$\begin{array}{l}\text { ln price main mineral } \\
\text { (homeland in country) }\end{array}$} \\
\hline$\times$ number of mines & $\begin{array}{c}0.562 \\
(0.012)\end{array}$ & $\begin{array}{c}0.284 \\
(0.119)\end{array}$ & $\begin{array}{c}0.374 \\
(0.091)\end{array}$ & $\begin{array}{c}0.141 \\
(0.111)\end{array}$ & $\begin{array}{c}0.979 \\
(0.167)\end{array}$ & $\begin{array}{c}0.717 \\
(0.212)\end{array}$ \\
\hline \multicolumn{7}{|l|}{$\begin{array}{l}\text { In price main mineral } \\
\text { (entire homeland) }\end{array}$} \\
\hline$\times$ number of mines & & & & & $\begin{array}{r}-0.107 \\
(0.047)\end{array}$ & $\begin{array}{r}-0.096 \\
(0.034)\end{array}$ \\
\hline \multirow{2}{*}{$\begin{array}{l}\text { In price main mineral } \\
\text { (in country outside homeland) } \\
\quad \times \text { number of mines }\end{array}$} & & & & & & \\
\hline & & & & & $\begin{array}{c}0.034 \\
(0.020)\end{array}$ & $\begin{array}{c}0.031 \\
(0.020)\end{array}$ \\
\hline Group $\times$ country fixed effects & Yes & Yes & Yes & Yes & Yes & Yes \\
\hline Year fixed effects & Yes & No & Yes & No & Yes & Yes \\
\hline Country $\times$ year fixed effects & No & Yes & No & Yes & No & No \\
\hline Observations & 2,352 & 2,226 & 2,352 & 2,226 & 2,352 & 2,352 \\
\hline
\end{tabular}

Notes: LPM estimations. Standard errors, clustered by group, in parentheses. The unit of observation is the rebel group-country-year. Sample without mine opening/closing over the period. Columns 3, 4, and 6 keep in the sample only cells which are located outside the ethnic homeland associated with the rebel group. Variables: In price main mineral (homeland in country) is the price of the main mineral produced in the ethnic homeland of the rebel group and in the considered country; In price main mineral (entire homeland) is the price of the main mineral produced in the ethnic homeland of the rebel group, inside or outside the considered country; In price main mineral (in country outside homeland) is the price of the main mineral produced inside the considered country but outside the ethnic homeland of the rebel group; main minerals are defined as the mineral produced in the largest number of cells at the beginning of the period. For each price variable, the associated number of mines variable denotes the number of mines producing the mineral in each respective area. All specifications include linear terms and interaction terms but only the coefficients of the interactions are displayed.

measurement errors - as the historical ethnic homelands information corresponds to a snapshot of the 1960 s.

Table 4 displays the estimation results (only interaction terms reported). In column 1, the dependent variable is (unrestricted) conflict incidence accounting for violence involving the rebel group $g$ within country of operation $i$ inside and outside its ethnic homeland. We control for group-country fixed effects and for year fixed effects. As expected, the coefficient of the interaction term is positive and statistically significant. Column 2 shows that the results of column 1 are robust to controlling for country-year fixed effects instead of year fixed effects. ${ }^{45}$ In columns 3 and 4 we replicate the specifications of columns 1-2 with a restricted definition of the dependent variable that now accounts for conflict incidence involving $g$ in country $i$, but only

\footnotetext{
${ }^{45}$ The reason why we favor year fixed effects in this table is two-fold. First, given the small number of observations, country $\times$ year results in a massive loss of degrees of freedom. Second, in columns 5 and 6 where we split price variations in several components-in the country, inside and outside homelands - the inclusion of country $\times$ year dummies would lead to a collinearity problem.
} 
outside the ethnic homelands of the rebel group. The estimates are similar (although below conventional statistical significance in column 4). This finding suggests that a rise in the price of minerals extracted in their ethnic homelands enables groups to increase their fighting activity outside their homeland. This is a first piece of evidence documenting the spatial diffusion of mining-induced violence.

In columns 5 and 6 we assess the role of international/ethnic borders by building an additional set of variables coding for minerals extracted in different geographic areas. More specifically for a given group $\times$ country of operation $\times$ year triplet, $(g, i, t)$, we consider a second interaction term between log prices and the number of mines in the entire homeland of $g$ (inside or outside $i$ ) and a third interaction term between $\log$ prices and the number of mines located in $i$ but outside the homeland of $g$; note that all the linear terms are also included (their point estimates are unreported). Column 5 displays the results for the unrestricted definition of conflict incidence and column 6 for the restricted one. As for the role of international borders, we find that the estimated coefficient of the second interaction term is negative $(-0.107)$ and significant at the 5 percent level. Together with the positive coefficient $(0.979)$ of the first interaction term (price shocks impacting only the ethnic homeland of $g$ in $i$ ), this finding suggests that international borders affect how price shocks translate into additional funding for rebel groups. Following an increase in mineral prices in the part of the ethnic homeland located in another country, an armed group $g$ operating in country $i$ tends to experience a reduction in its fighting activity. Our interpretation is that the now richer coethnics abroad may prefer to fund local rebels who may be better placed to get their hands on the now more lucrative resource rents in the foreign country. Note that the sum of the two coefficients is positive $(0.979-0.107=0.872)$, which implies that the overall conflict probability increases after a price shock in the ethnic homeland; but the conflict tends to relocate in the country where the mines are. As for the role of ethnic borders, we find that the estimated coefficient of the third interaction term is positive, but 30 times smaller than the coefficient of the first interaction term. This evidence supports our hypothesis that rebel groups benefit relatively more from the extractive rents of mines located in their ethnic homeland. Finally, it is worth mentioning that these results are to be viewed with caution: the main coefficients are identified thanks to the few rebel groups whose ethnic homeland is spread over several countries and contain mines producing distinct minerals. ${ }^{46}$

\section{B. Changes in Territory}

A second approach consists in assessing directly the impact of conquering a mining area after a victorious battle on groups' future fighting activity. For each battle, our data detail the name and type of fighting groups on each side (government, rebel groups, militias, foreign powers, civilians) and the outcome of the battle (who won

\footnotetext{
${ }^{46}$ Online Appendix Section U contains supplementary material. In particular we replicate in Table A.30 the results of Table 4, but using a weighted price index of all minerals present instead of the price of the main mineral. To capture the diffusion of violence from mining areas to nonmining areas, we replicate in Table A.31 the results of Table 4 when restricting the dependent variable to conflicts occurring in cells located outside mining areas.
} 
and gained (or kept) the territory). As discussed above, this information allows for studying diffusion and helps identifying the feasibility mechanism.

We build a balanced dataset containing, for each rebel group, all combinations of grid cells $\times$ years where the group can potentially be active (i.e., all cells located in the countries of operation of the group). Therefore, our unit of observation is now a grid cell $\times$ year $\times$ rebel group. Our idea is to test whether a change in territory has more effect on future rebel activity elsewhere if the territory is a mining area. To test for this diffusion over space and time of mining-induced battles, we restrict our analysis to rebel groups that have been active in period $t-1$ and estimate a LPM of the probability of outbreak of a new event involving a group $g$ in cell $k$ in year $t$ :

$$
\text { ONSET }_{g k t}=\alpha \times \text { BATTLE }_{g t-1}^{0}+\beta \times \text { BATTLE }_{g t-1}^{m}+\mathbf{F E}_{g k}+\mathbf{F E}_{i t}+\varepsilon_{g k t},
$$

where $\mathbf{F E}_{\mathrm{gk}}$ are group $\times$ cell fixed effects, and $\mathbf{F E}_{i t}$ are country of operation $\times$ year fixed effects. Here, ONSET $_{g k, t}$ is a binary variable equal to 1 if group $g$ is involved in an event in year $t$ in a cell $k$ that was at peace in $t-1$; it is 0 if the cell is still in peace in year $t$. Notice that we deliberately focus on event outbreak and not on incidence; henceforth the observation is dropped out of the sample if $g$ perpetrates violence in $k$ in $t-1$. Our main explanatory variables are BATTLE $g_{g, t-1}^{m}$ and BATTLE $_{g, t-1}^{0}$. The first corresponds to the total number of battles won by group $g$ in $t-1$ in mining areas; the second is the number of battles won in $t-1$ in nonmining areas. ${ }^{47}$ The two coefficients $\alpha$ and $\beta$ could be either positive or negative depending on the underlying process governing the dynamics of battles: negative if battle occurrence is mean-reverting; positive in the presence of unobserved transient shocks that, for example, impact the fighting capacity of a group. However, our test of the spatial and time diffusion of mining-induced violence does not rest upon the absolute level of these coefficients but on their relative value, as we expect $\beta>\alpha$ : winning in $t-1$ a territory containing active mining increases the probability of battle onset in other cells in $t$ more than winning a territory with no active mine. The implicit assumption here is that winning a battle in a mining area enables rebel groups to appropriate mining rents. In all specifications, the standard errors are clustered at the same level than our main explanatory variables, namely at the rebel group level (we explore other levels of clustering in the robustness analysis).

Before turning to regression results, we first report some simple statistics (see also Table A.32 in online Appendix). The sample size is larger $(204,402$ observations) as the unit of observation is now a grid cell $\times$ year $\times$ group. It contains 126 groups operating in 32 countries. Each group operates in 1.7 countries on average (with a maximum of 6 countries). The dependent variable ONSET $_{g k, t}$ is equal to 1 for 2,019 observations ( 0.99 percent of the observations). The number of battles won in $t-1$ is positive for 42 percent of observations. Among these, 4 percent correspond to battles won in mining areas (2,940 observations). This may seem to be a large amount of observations, but it actually represents only 1.4 percent of the sample size and 54 events. This data limitation prevents us from including an interaction term with the world price of minerals.

\footnotetext{
${ }^{47}$ We include the establishment of headquarters in the battles won, as it is also a case of rebel groups gaining the territory.
} 
Table 5 displays the regression results. Only the subsample of rebel groups active in $t-1$ is considered. In column 1 the explanatory variable corresponds to the total number of battles won by a rebel group in the previous period. From column 2 onward, we estimate equation (3) where battles won in mining areas are accounted for separately from those won in nonmining areas. While in column 2 the two variables of battles won are binarized, in column 3 we look at the number of battles won. In both cases, we find that $\beta$ is statistically significantly larger than $\alpha$. This finding shows that the appropriation of mining areas increases the probability of perpetrating violence elsewhere in the territory one year after. We interpret it as supportive of the view that mineral rents finance rebellions.

One potential selection bias in our estimation could arise if groups attacking mines have unobserved characteristics different from the groups engaged in battles in nonmining areas. Note, however, that time-invariant group differences are filtered out by group $\times$ cell fixed effects. Still, time-varying group characteristics could correlate with the decision to fight in mining areas, e.g., a situation where groups get stronger or weaker over time and only dare attack a mine when they are strong. To check that our results are not driven by such unobserved transient shocks affecting groups' fighting capacity, we include in column 4 measures of battles fought inside/ outside mining areas that did not result in a change of territory. The absence of territorial change does not necessarily mean that the rebels lost, but rather could indicate an indecisive battle or a situation where rebels successfully managed to keep control of previously conquered territory. Still, we expect the effect to be larger when rebels manage to conquer the mining territory. The estimation results confirm our previous finding that $\beta$ is statistically significantly larger than $\alpha$. Interestingly, for battles in mining areas, the coefficient associated with the absence of territorial change is five times smaller than the one associated with winning a battle, in line with the logic described above.

We now document the time and spatial decays. In columns 5 and 6 we include battles won in $t-2$ and in $t-3$, and our main finding can be observed at different time lags (i.e., $\beta>\alpha$ ). Columns 7-8 start from specifications of columns 1 and 3 and add interaction terms between the lagged battles variables and their average distance to the cell's centroid. A clear pattern of spatial decay emerges. This evidence can be seen in more details in Figure 2 where we have plotted the marginal effect of battles won in $t-1$ on the probability of conflict onset in $t$ as a function of distance to the battles (based on the estimates of column 8). The change in conflict probability is small and nonsignificant if a territory containing no mine was won (panel A). In cases where battles occurred in mining areas (panel B), the probability increases by up to 20 percentage points in the areas surrounding the battles, and remains significant up to 1,000 kilometers around. This clearly suggests that mining-induced violence does diffuse across space.

Finally we can quantify in a simple way the extent to which the conquest of a mining area exacerbates future violence. The appropriation of a mining area in year $t$ increases by 4 percentage points the cell-level probability of an event occurring in year $t+1$. Given that a rebel group is active in 335 cells on average, this leads to $0.040 \times 335=13.4$ additional events (Table 5, column 2). This represents a tripling in rebel fighting activity (average number of events by group-year being 3.78). Admittedly, this back-of-the-envelope calculation is very rough. But it supports the 
TABLe 5-Feasibility AND the Diffusion of WAR

\begin{tabular}{|c|c|c|c|c|c|c|c|c|}
\hline \multirow{3}{*}{ Estimator } & \multicolumn{8}{|c|}{ Conflict onset } \\
\hline & \multicolumn{8}{|c|}{ LPM } \\
\hline & $(1)$ & $(2)$ & (3) & (4) & (5) & (6) & $(7)$ & (8) \\
\hline \# battles ${ }_{g, t-1}$ & $\begin{array}{c}0.002 \\
(0.002)\end{array}$ & & & & & & $\begin{array}{c}0.033 \\
(0.015)\end{array}$ & \\
\hline Battle $_{g, t-1}^{0}$ & & $\begin{array}{c}0.000 \\
(0.002)\end{array}$ & & & & & & \\
\hline Battle $_{g, t-1}^{m}$ & & $\begin{array}{c}0.040 \\
(0.012)\end{array}$ & & & & & & \\
\hline$\#$ battles ${ }_{g, t-1}^{0}$ & & & $\begin{array}{c}0.001 \\
(0.002)\end{array}$ & $\begin{array}{r}-0.001 \\
(0.002)\end{array}$ & $\begin{array}{c}0.000 \\
(0.002)\end{array}$ & $\begin{array}{c}0.000 \\
(0.002)\end{array}$ & & $\begin{array}{c}0.029 \\
(0.014)\end{array}$ \\
\hline$\#$ battles ${ }_{g, t-1}^{m}$ & & & $\begin{array}{c}0.053 \\
(0.016)\end{array}$ & $\begin{array}{c}0.041 \\
(0.017)\end{array}$ & $\begin{array}{c}0.062 \\
(0.013)\end{array}$ & $\begin{array}{c}0.054 \\
(0.013)\end{array}$ & & $\begin{array}{c}0.600 \\
(0.184)\end{array}$ \\
\hline \# battles ${ }_{g, t-1}^{0}$ (no change of terr.) & & & & $\begin{array}{c}0.001 \\
(0.001)\end{array}$ & & & & \\
\hline \# battles ${ }_{g, t-1}^{m}$ (no change of terr.) & & & & $\begin{array}{c}0.008 \\
(0.003)\end{array}$ & & & & \\
\hline$\#$ battles ${ }_{g, t-2}^{0}$ & & & & & $\begin{array}{r}-0.000 \\
(0.001)\end{array}$ & $\begin{array}{c}0.000 \\
(0.001)\end{array}$ & & \\
\hline \# battles ${ }_{g, t-2}^{m}$ & & & & & $\begin{array}{c}0.023 \\
(0.009)\end{array}$ & $\begin{array}{c}0.021 \\
(0.008)\end{array}$ & & \\
\hline$\#$ battles ${ }_{g, t-3}^{0}$ & & & & & & $\begin{array}{c}-0.004 \\
(0.001)\end{array}$ & & \\
\hline \# battles ${ }_{g, t-3}^{m}$ & & & & & & $\begin{array}{c}0.030 \\
(0.016)\end{array}$ & & \\
\hline In average distance to battles $s_{t-1}$ & & & & & & & $\begin{array}{c}-0.001 \\
(0.003)\end{array}$ & $\begin{array}{l}-0.001 \\
(0.003)\end{array}$ \\
\hline \# battles ${ }_{g, t-1} \times \ln$ av. dist. & & & & & & & $\begin{array}{c}-0.005 \\
(0.002)\end{array}$ & \\
\hline$\#$ battles ${ }_{g, t-1}^{0} \times \ln$ av. dist & & & & & & & & $\begin{array}{r}-0.004 \\
(0.002)\end{array}$ \\
\hline$\#$ battles ${ }_{g, t-1}^{m} \times \ln$ av. dist & & & & & & & & $\begin{array}{c}-0.084 \\
(0.027)\end{array}$ \\
\hline $\begin{array}{l}\text { Difference in coefs. } \\
\text { \# battles }{ }_{g, t-1}^{m}-\# \text { battles } g_{g, t-1}^{0}\end{array}$ & & $\begin{array}{c}0.039 \\
(0.012)\end{array}$ & $\begin{array}{c}0.056 \\
(0.016)\end{array}$ & $\begin{array}{c}0.042 \\
(0.016)\end{array}$ & $\begin{array}{c}0.061 \\
(0.014)\end{array}$ & $\begin{array}{c}0.053 \\
(0.013)\end{array}$ & & \\
\hline - no change of terr. & & & & $\begin{array}{c}0.007 \\
(0.003)\end{array}$ & & & & \\
\hline Country $\times$ year fixed effects & Yes & Yes & Yes & Yes & Yes & Yes & Yes & Yes \\
\hline Group $\times$ cell fixed effects & Yes & Yes & Yes & Yes & Yes & Yes & Yes & Yes \\
\hline Observations & 168,887 & 168,887 & 168,887 & 168,887 & 168,887 & 158,040 & 168,887 & 168,887 \\
\hline
\end{tabular}

Notes: LPM estimations. Standard errors, clustered by group, in parentheses. The unit of observation is the cell-rebel group-year. Only the sample of rebel groups active in $t-1$ is considered. Singletons are dropped. Variables: \# battles ${ }_{g, t-1}$, \# battles ${ }_{g, t-1}^{0}$, and \# battles ${ }_{g, t-1}^{m}$ are the number of battles won in $t-1$, respectively in total, in nonmining areas and in mining areas; no change of terr. means that the number of battles with no change in territory in considered; \# battles variables are expressed as $\log (x+1)$; ln average distance to battles ${ }_{t-1}$ is the average distance between the cell and all previous year's battles. 
Panel A. No mines won in $t-1$

Effect of \# battles won in $t-1$ on conflict outbreak in $t$

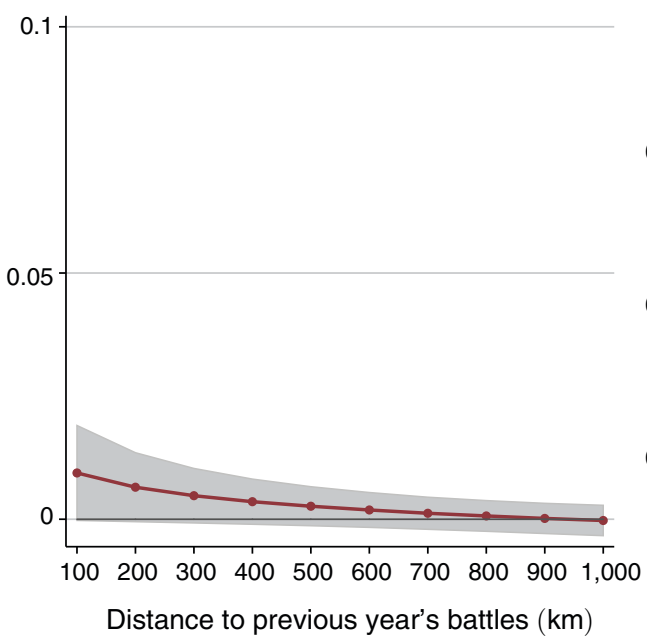

Panel B. Mines won in $t-1$

Effect of \# battles won in $t-1$ on conflict outbreak in $t$

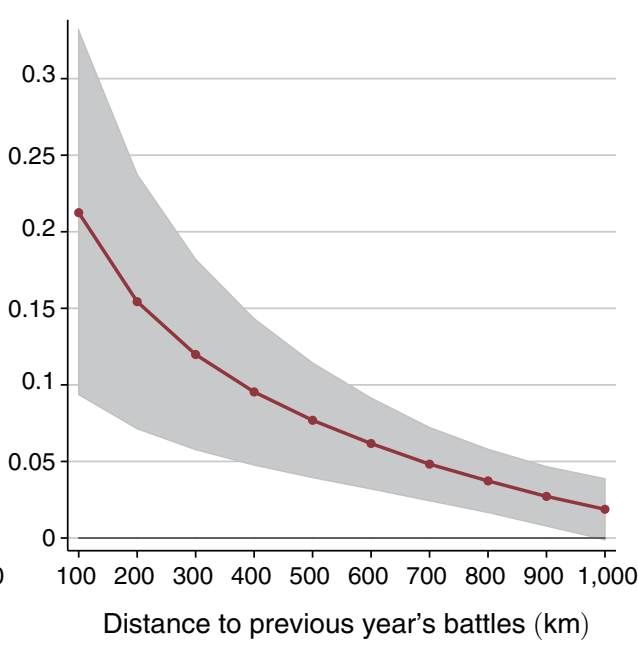

Figure 2. Feasibility and the Spatial Diffusion of Conflicts

view that mining activity, arguably through the feasibility channel, is an important driver of escalation from local violence to large-scale conflict. ${ }^{48}$

\section{Breaking the Resource Curse: The Role of Mining Companies}

The previous section has focused on the role of fighting groups in mininginduced violence. But mining companies also may play an important part. In this section, we study specifically the role of companies' characteristics and management practices on the presence of violence. A recent case reported by the NGO Global Witness (2016) illustrates our approach well. A Chinese mining company, Kun Hou Mining, is accused of having extracted gold from the Ulindi River in South Kivu (DRC) between 2013 and 2015 with the support of both local corrupt authorities and armed groups. To operate in the area and secure access, the company provided the armed groups operating on the banks of the river (the Raia Mutumboki militias) with money, rations, AK-47 rifles, and other items which allowed the militias to extort gold from artisanal miners extracting minerals in the same area. These activities occurred thanks to the cooperation of the local authorities of South-Kivu, which covered up the presence of Kun Hou Mining in the region and its links with local armed groups. Similarly, the governmental agency in charge of protecting local small-scale miners cooperated with the local militias to collect illegal taxes from the miners. No formal fiscal revenue from alluvial gold mining was recorded in the South-Kivu province over the period. Meanwhile, the gold was sold and smuggled to Dubai by

\footnotetext{
${ }^{48}$ Section V in the online Appendix contains additional results. Table A.33 uses spatially clustered standard errors and Table A.34 allows for two-way clustering of standard errors by group and cells. The significance levels are very similar to the ones reported in Table 5. Finally, in Table A.35 the dependent variable is outbreak of battle events only (instead of all events).
} 
a trader from Bukavu, Alpha Gold. This story fits perfectly the main findings discussed below: the extraction by a foreign-owned company of a precious and easy-tosmuggle mineral fueled conflict by providing local armed groups with financial and material means to sustain and enlarge their activities. Both bribery by the company and extortion by rebel groups were observed. Local corruption-in the extraction area and along the trading routes_-played its part by facilitating and participating in the entire process. Global regulations on transparency and traceability were ignored.

\section{A. Companies' Characteristics: Does Mine Ownership Matter?}

By operating mines in conflict-prone environments, companies potentially become a central feature of the circumstances conducive to violence. At the local level, they could be more or less willing to secure mining areas where they plan to operate (e.g., with the help of governmental troops or private militias). Even more importantly, conflict may be escalated by companies propensity to finance, often through bribes or other illegal and opaque ways, the rebel groups that control the territories surroundings the mines. The terms of an implicit agreement are often bribes that in exchange for protection by rebel groups in order to guarantee companies' ability to operate in large-scale extraction. For these reasons, understanding the role of firms' behavior is of foremost importance, both from a positive and policy perspective. ${ }^{49}$ To this end we exploit a unique feature of our dataset, i.e., its information on the identity of the owning company and the country of its headquarters.

Let us start with a brief overview of the companies present in our dataset (Table A.36 in the online Appendix displays more detailed descriptive statistics). Foreign-owned firms represent on average 60 percent of the companies; 12 percent of the mines are publicly owned by the domestic government and the residual category is composed of domestic private firms. We should expect that not all foreign firms benefit from the same level of protection by the domestic government. As discussed in more detail below, there is a vast literature showing that firms from the ex-colonizing power continue to benefit from privileged relationships with the new rulers after decolonization (see, e.g., Stockwell 2000; White 2000; Cain and Hopkins 2016). Henceforth, we distinguish between firms from a foreign colonizer country versus firms from a foreign country with no colonial ties to the country where the mine is located. Among foreign firms, roughly one-fifth have their headquarters located in the formerly colonizing country.

In Table 6, we investigate how the type of ownership impacts mining-induced violence. We start from the specification of column 2 of baseline Table 2.50 Mutually exclusive categories of ownership, FOREIGN FIRMS, DOMESTIC PUBLIC FIRMS, and DOMESTIC PRIVATE FIRMS are coded as the share of firms in a given cell belonging to this given category, and is interacted with our main effect $\left(M_{k} \times \ln p_{k t}^{W}\right)$. We retain the ownership status at the beginning of the sample period for the sake of exogeneity

\footnotetext{
${ }^{49}$ While, as discussed above, there has been some related work on the impact of institutions on the resource curse, the modulating role of firm characteristics is severely under-studied. One of the reasons for this gap in the literature is that in most datasets precise firm characteristics are missing.

${ }^{50}$ We replicate in Table 16 the analogous analysis, focusing on the second baseline specification from the benchmark Table 2 , namely column 4 . The results are very similar for overall conflict incidence, but become weaker for battles (missing the conventional threshold for significance).
} 
Table 6-Mineral Price, Firm Ownership, and Conflicts

\begin{tabular}{|c|c|c|c|c|c|c|}
\hline \multirow{4}{*}{$\begin{array}{l}\text { Estimator } \\
\text { Sample } \\
\text { Dependent variable } \\
\text { Events }\end{array}$} & \multicolumn{6}{|c|}{ LPM } \\
\hline & \multicolumn{6}{|c|}{$V\left(M_{k t}\right)=0$} \\
\hline & \multicolumn{6}{|c|}{ Conflict incidence } \\
\hline & $\begin{array}{l}\text { All } \\
(1)\end{array}$ & $\begin{array}{c}\text { Battles } \\
(2)\end{array}$ & $\begin{array}{l}\text { All } \\
(3)\end{array}$ & $\begin{array}{c}\text { Battles } \\
(4)\end{array}$ & $\begin{array}{l}\text { All } \\
(5)\end{array}$ & $\begin{array}{c}\text { Battles } \\
(6)\end{array}$ \\
\hline ln price $\times$ mines $>0 \times$ foreign firms & $\begin{array}{c}0.101 \\
(0.038)\end{array}$ & $\begin{array}{c}0.030 \\
(0.016)\end{array}$ & & & & \\
\hline ln price $\times$ mines $>0 \times$ dom. private firms & $\begin{array}{c}0.035 \\
(0.030)\end{array}$ & $\begin{array}{c}-0.002 \\
(0.006)\end{array}$ & $\begin{array}{c}0.034 \\
(0.030)\end{array}$ & $\begin{array}{c}-0.002 \\
(0.006)\end{array}$ & $\begin{array}{c}0.047 \\
(0.052)\end{array}$ & $\begin{array}{c}-0.007 \\
(0.017)\end{array}$ \\
\hline ln price $\times$ mines $>0 \times$ dom. public firms & $\begin{array}{c}0.027 \\
(0.037)\end{array}$ & $\begin{array}{c}-0.006 \\
(0.011)\end{array}$ & $\begin{array}{c}0.026 \\
(0.036)\end{array}$ & $\begin{array}{c}-0.007 \\
(0.011)\end{array}$ & $\begin{array}{c}0.026 \\
(0.036)\end{array}$ & $\begin{array}{r}-0.006 \\
(0.011)\end{array}$ \\
\hline ln price $\times$ mines $>0 \times$ fgn firms $($ col . $)$ & & & $\begin{array}{c}0.022 \\
(0.037)\end{array}$ & $\begin{array}{c}-0.008 \\
(0.026)\end{array}$ & $\begin{array}{c}0.035 \\
(0.048)\end{array}$ & $\begin{array}{c}-0.012 \\
(0.025)\end{array}$ \\
\hline ln price $\times$ mines $>0 \times$ fgn firms (non col. $)$ & & & $\begin{array}{c}0.150 \\
(0.052)\end{array}$ & $\begin{array}{c}0.053 \\
(0.020)\end{array}$ & $\begin{array}{c}0.159 \\
(0.047)\end{array}$ & $\begin{array}{c}0.050 \\
(0.022)\end{array}$ \\
\hline ln price $\times$ mines $>0 \times$ large firms & & & & & $\begin{array}{c}-0.018 \\
(0.054)\end{array}$ & $\begin{array}{c}0.006 \\
(0.022)\end{array}$ \\
\hline Country $\times$ year fixed effects & Yes & Yes & Yes & Yes & Yes & Yes \\
\hline Cell fixed effects & Yes & Yes & Yes & Yes & Yes & Yes \\
\hline Observations & 142,072 & 142,072 & 142,072 & 142,072 & 142,072 & 142,072 \\
\hline
\end{tabular}

Notes: LPM estimations. Conley (1999) standard errors in parentheses, allowing for spatial correlation within a $500 \mathrm{~km}$ radius and for infinite serial correlation. Variables: mines $>0$ is a dummy taking the value 1 if at least 1 mine is active in the cell in year $t ; V\left(M_{k t}\right)=0$ means that we consider only cells in which the mine dummy takes always the same value over the period; ln price main mineral is the world price of the mineral with the highest production over the period (evaluated at 1997 prices) for mining cells, and zero for nonmining cells. The company characteristics (foreign, domestic public, domestic private, etc.) denote the share of mine owned by a given category at the beginning of the period. Cells containing only mines with missing ownership information are dropped.

(i.e., self-selection). As these three shares sum up to 1 , the baseline interaction term $\left(M_{k} \times \ln p_{k t}^{W}\right)$ is dropped from the specification to avoid collinearity. In all oddnumbered columns the dependent variable is conflict incidence, while in all even columns the dependent variable is restricted to incidence of battles only, for which the role of political protection and connections arguably are particularly salient.

Columns 1-2 of Table 6 display the coefficients of the interaction term for each category of ownership. In both columns the share of foreign firms has a positive and statistically significant impact, meaning that a larger presence of foreign firms magnifies the impact of mineral price shocks on conflict. In contrast, we do not detect any statistically significant effect for domestic firms. This finding is consistent with at least two explanations. First, it could be that domestically owned companies are better protected by the national army and hence more resistant to capture by rebels (who are deterred to attack them), and/or second, it could be that domestic firms are more reluctant to pay bribes and extortion money, which would make indirect control of the mining area by rebel forces less lucrative. Of course, the two explanations may well be intertwined. A firm more protected by the state is less willing to give in to demands for protection money by rebels operating in a given area. By analogy, the fact that we find strongly significant effects for foreign firms is consistent with the view that mining areas operated by foreign firms are less well protected, and/or the view that foreign firms are more willing to pay extortion money to rebels. 
As mentioned above, it is reasonable to expect firms from former colonizers to have privileged access to government circles and to benefit from similar insider protection as domestic firms receive. For example, a US firm operating in a country with a traditionally left-leaning government may not be as well protected as a firm originating in a country with strong connections to the local elite, such as, say, a Belgian company operating in the Democratic Republic of Congo, or a British firm doing business in Ghana. 51

In columns 3-4 we replicate columns 1-2 with the foreign firms category that is now split into foreign firms from former colonizer country (FGN FIRMS (COL.)) and foreign firms without colonial ties (FGN FIRMS (NON COL.)). We find striking differences. Foreign firms with headquarters in the former colonizer country are very comparable to domestic state-owned firms as they are not associated with any political instability after mineral price shocks. In contrast, mines owned by foreign firms without colonial ties experience a quantitatively large, statistically significant effect on boosting the conflict potential when mineral prices rise. ${ }^{52}$ Again, this finding could be due to greater vulnerability of mining firms in the absence of state protection, and/or to dirty business practices such as paying bribes and extortion money that could invite mining area takeovers by rebels. In columns 5-6, we replicate the columns 3-4 and in addition control for the interaction with LARGE FIRM, a dummy variable coding for large firms. ${ }^{53}$ The results are unchanged, meaning that the previous finding is not a sheer size effect.

\section{B. Promoting Good Practices: Does Transparency Matter?}

A government that is respectful of property rights may find it difficult to engineer the ownership status of mining companies operating in its national territory. Yet, policy interventions targeting bribing practices of mining companies might be able to curb conflict. International policy makers have recently started to promote transparency and traceability in the mining industry. Examples include the US legislation requiring US firms to certify that their purchases of particular minerals are $D R C$ conflict free, or the recent framework adopted by the EU commission (on June 16, 2016) to force companies to track the origin of minerals produced in conflict-prone areas. In the same vein, several international initiatives aiming at encouraging good

\footnotetext{
${ }^{51}$ Indeed, there is a vast literature on the persistence of economic ties in the post-colonial era (see Cain and Hopkins 2016). For example, for the case of British companies in Ghana, Stockwell (2000, p. 237) points out that "businessmen, like other non-officials, experienced decolonization not just as passive observers of a constitutional readjustment, but as active participants in a complicated process involving the reorganization and adaptation of their activities, a reexamination of their employment policies, and a renegotiation of their relationships with a changing pattern of state structures and political forces" and that "established British companies continue to retain a strong presence in Ghana today." Also White (2000, p. 545) concludes that British firms managed to maintain their influence after decolonization, and that "the transfer of political power for British firms in territories such as Malaya, the Gold Coast, and Kenya was favourable as independent regimes remained in the sterling area and chose development strategies heavily reliant on foreign investment. Even for territories where more statist development models were followed, such as Nigeria, British commercial banks, shipping lines, and import-export firms were remarkably successful in maintaining their positions."

${ }^{52}$ The difference between the triple interaction coefficients of FOREIGN FIRMS (COLONIZER) and FOREIGN FIRMS (NON COLONIZER) misses the conventional threshold for statistical significance in column 3 but is statistically significant in column 4.

${ }^{53}$ We use information provided by the RMD dataset about whether the owner of the mine is a major company, i.e., if the corresponding company belongs to the world top ten in terms of production of the corresponding mineral in a given year. About 60 percent or foreign firms belong to the group of these large multinational firms.
} 
Table 7-Heterogeneous Effects: The Role of Transparency

\begin{tabular}{|c|c|c|c|c|c|c|c|c|c|c|}
\hline \multirow{4}{*}{$\begin{array}{l}\text { Estimator } \\
\text { Sample } \\
\text { Dependent variable } \\
\text { Events }\end{array}$} & \multicolumn{10}{|c|}{ LPM } \\
\hline & \multicolumn{10}{|c|}{$V\left(M_{k t}\right)=0$} \\
\hline & \multicolumn{10}{|c|}{ Conflict incidence } \\
\hline & $\begin{array}{l}\text { All } \\
(1)\end{array}$ & $\begin{array}{c}\text { Battles } \\
(2)\end{array}$ & $\begin{array}{l}\text { All } \\
(3)\end{array}$ & $\begin{array}{c}\text { Battles } \\
\text { (4) }\end{array}$ & $\begin{array}{l}\text { All } \\
(5)\end{array}$ & $\begin{array}{c}\text { Battles } \\
(6)\end{array}$ & $\begin{array}{l}\text { All } \\
(7)\end{array}$ & $\begin{array}{c}\text { Battles } \\
(8)\end{array}$ & $\begin{array}{l}\text { All } \\
(9)\end{array}$ & $\begin{array}{c}\text { Battles } \\
(10)\end{array}$ \\
\hline ln price $\times$ mines $>0$ & $\begin{array}{c}0.002 \\
(0.057)\end{array}$ & $\begin{array}{c}0.028 \\
(0.036)\end{array}$ & $\begin{array}{c}0.045 \\
(0.024)\end{array}$ & $\begin{array}{c}0.043 \\
(0.025)\end{array}$ & $\begin{array}{c}0.066 \\
(0.047)\end{array}$ & $\begin{array}{c}0.048 \\
(0.038)\end{array}$ & $\begin{array}{c}0.045 \\
(0.025)\end{array}$ & $\begin{array}{c}0.043 \\
(0.026)\end{array}$ & $\begin{array}{c}0.062 \\
(0.034)\end{array}$ & $\begin{array}{c}0.025 \\
(0.021)\end{array}$ \\
\hline$\times$ large firms & $\begin{array}{c}0.130 \\
(0.069)\end{array}$ & $\begin{array}{c}-0.013 \\
(0.039)\end{array}$ & $\begin{array}{c}0.120 \\
(0.064)\end{array}$ & $\begin{array}{c}-0.008 \\
(0.032)\end{array}$ & $\begin{array}{c}0.076 \\
(0.066)\end{array}$ & $\begin{array}{c}-0.023 \\
(0.039)\end{array}$ & $\begin{array}{c}0.092 \\
(0.059)\end{array}$ & $\begin{array}{c}-0.020 \\
(0.034)\end{array}$ & $\begin{array}{c}0.069 \\
(0.061)\end{array}$ & $\begin{array}{c}-0.003 \\
(0.028)\end{array}$ \\
\hline$\times$ control of corruption & $\begin{array}{c}-0.105 \\
(0.038)\end{array}$ & $\begin{array}{c}-0.041 \\
(0.016)\end{array}$ & & & & & & & & \\
\hline$\times$ firm CSR $($ ICMM $)$ & & & $\begin{array}{c}-0.224 \\
(0.067)\end{array}$ & $\begin{array}{c}-0.085 \\
(0.038)\end{array}$ & & & & & & \\
\hline$\times$ tracea. init. $($ EITI, request $)$ & & & & & $\begin{array}{c}-0.004 \\
(0.004)\end{array}$ & $\begin{array}{c}-0.001 \\
(0.002)\end{array}$ & & & & \\
\hline$\times$ tracea. init. (EITI, comply) & & & & & & & $\begin{array}{c}-0.007 \\
(0.003)\end{array}$ & $\begin{array}{c}-0.001 \\
(0.001)\end{array}$ & & \\
\hline$\times$ tracea. init. $(\mathrm{GLR})$ & & & & & & & & & $\begin{array}{c}-0.004 \\
(0.002)\end{array}$ & $\begin{array}{c}0.005 \\
(0.004)\end{array}$ \\
\hline Country $\times$ year fixed effects & Yes & Yes & Yes & Yes & Yes & Yes & Yes & Yes & Yes & Yes \\
\hline Cell fixed effects & Yes & Yes & Yes & Yes & Yes & Yes & Yes & Yes & Yes & Yes \\
\hline Observations & 131,026 & 131,026 & 141,624 & 141,624 & 141,610 & 141,610 & 141,610 & 141,610 & 141,610 & 141,610 \\
\hline
\end{tabular}

Notes: LPM estimations. Conley (1999) standard errors in parentheses, allowing for spatial correlation within a $500 \mathrm{~km}$ radius and for infinite serial correlation. Sample restricted to nonmining cells and cells for which foreign-owned mines represent the largest share. Variables: mines $>0$ is a dummy taking the value 1 if at least 1 mine is active in the cell in year $t ; V\left(M_{k t}\right)=0$ means that we consider only cells in which the mine dummy takes always the same value over the period; ln price main mineral is the world price of the mineral with the highest production over the period (evaluated at 1997 prices) for mining cells, and zero for nonmining cells. See main text for a description of the various transparency variables.

practices among extractive companies and tracking the origins of minerals are underway. For instance, the Mineral Certification Scheme of the International Conference on the Great Lakes Region (ICGLR) tracks the sales of gold, cassiterite, wolframite, and coltan. Similar certification efforts are observed in the tin and tantalum industries. Several countries have adopted international standards for managing the extractive rent in an open and accountable way, e.g., by fully disclosing royalties.

While many conceptual policy memos have been written on transparency and certification schemes, so far there is virtually no hard evidence on the conflict-decreasing impact of these schemes in reality. ${ }^{54}$ We address this issue in Table 7. We take as the starting point column 2 of the baseline Table 2 and focus on a battery of triple interactions. As before, all odd-numbered columns have conflict incidence as dependent variable, while the even columns restrict attention to battle incidence only. The analysis is restricted to foreign firms, which is the category of firms that drives most of the conflict-fueling effect of mining price spikes (see Table 6). These firms are likely to receive weaker government protection and may be more vulnerable to corruption and extortion, as discussed in the previous subsection. We exclude from the sample

\footnotetext{
${ }^{54}$ With the notable recent exception of Heffernan (2016), who look at the effect of the Kimberley Process using cross-country panel data and find a conflict-reducing effect.
} 
all mines that are not foreign-owned. Note also that in all columns we control for the triple interaction with the dummy for large firms to account for scale effects.

In Appendix Table 13 discussed earlier, we found in the whole sample of mining companies and conflict events that mining price spikes had a somewhat attenuated impact in countries with a powerful control of corruption. In columns 1 and 2, we show that this result is reinforced in the case of foreign firms and battle events: the interaction of mining price shocks with CONTROL OF CORRUPTION, the measure already used in Table 13, is negative and significant at the 1 or 5 percent level. ${ }^{55}$ In columns 3 and 4, we interact mining price shocks with a variable representing the share of companies which are members of the International Council on Mining and Metals (ICMM), a network of companies promoting Corporate Social Responsibility in the mining industry. ${ }^{56}$ In both columns, the coefficient of the triple interaction with CSR practices has the expected negative sign and is statistically significant, suggesting that corporate social responsibility can indeed build viable resistance to the resource curse.

Could top-down initiatives at the country level to foster good practices also have this dampening effect? In columns 5-10, we look at two country-level transparency initiatives, the Extractive Industries Transparency Initiative (EITI) and the Mineral Certification Scheme of the International Conference on the Great Lakes Region (ICGLR). The former initiative holds its member countries accountable to fully disclose taxes and payments made by mining companies to their governments; the latter tracks the origin of a number of metals. Among other things, the ICGLR aims at identifying mines which are related to conflicts, e.g., through illegal control, taxation, or extortion. 57

In each specification, we interact mineral prices with a dummy coding for country membership (for the relevant minerals in the case of ICGLR). For the EITI initiative, we use data on the country-specific dates of EITI membership from Papyrakis, Rieger, and Gilberthorpe (2017). We first use the date at which the country becomes a candidate country. The application process generally lasts several years, at the end of which the country produces and submits a validation report that shows compliance with the EITI criteria and establishes the country case for membership in the initiative. As a second indicator, we use the year during which the validation report was submitted. ${ }^{58}$ In columns $5-6$ we code a country as EITI

\footnotetext{
${ }^{55}$ An alternative to focusing on country-level measures of corruption is to use corruption proxies at a more disaggregate level, which may be less noisy. In online Appendix Section P, we rely on gaps in the declarations of importers and exporters as a proxy for port-level corruption, finding evidence consistent with the notion that our proxy of port-level corruption may induce conflict.

${ }^{56} \mathrm{See}$ http://www.icmm.com. It is important to note that membership to ICMM is endogenous to a variety of factors, and hence the results presented here should be taken with a grain of salt. In particular, it may be the case that companies deciding to join the ICMM are located in more stable areas which makes it less costly for them to join the ICMM. Indeed, in our data the conflict probability is twice lower in areas in which ICMM companies are present, even before the creation of ICMM in 2001.

${ }^{57}$ For the Extractive Industries Transparency Initiative (EITI), see https://eiti.org/eiti and http://www.pacweb. org/en/regional-certification. For the Mineral Certification Scheme of the International Conference on the Great Lakes Region (GLR), see http://www.oecd.org/investment/mne/49111368.pdf.

${ }^{58}$ The country is generally granted membership during the same year or in the year after submitting the report. We chose to use the date at which the report was submitted rather than the date at which membership was granted because of data limitations: our period of study ends in 2010, and only three countries were granted membership at this date (Ghana, Niger, and Liberia), two of which are very small. Considering the date at which the report was submitted allows to consider the effect on three (large) additional countries (Nigeria, Mauritania, and Mali).
} 
member from the date when it requested adhesion. The triple interaction of interest has the expected sign but is not statistically significant. In columns 7-8, we take an alternative stand and code a given country as EITI member only when it has submitted the final validation report. With this more restrictive definition of membership, we detect a conflict-dampening effect of EITI membership in column 7 (which turns insignificant for battles in column 8). In sum, mining price spikes tend to have a less detrimental effect in EITI countries, provided that they have already started adhering to EITI rules. Note, however, that compliance to EITI standards occurred only in few countries in our sample period, hence these results need to be interpreted cautiously. A proper evaluation of the impact of these policies would imply using a dataset with an extended time period. Finally, column 9 shows that the conflict-inducing effect of mineral price rises is less severe in countries that have adhered to the GLR mineral certification scheme, while in column 10 no effect is detected for battle incidence. 59

\section{Conclusion}

This paper provides a systematic analysis of the impact of all major mineral extraction on the likelihood of armed conflict in Africa, using novel and fine-grained panel data with a spatial resolution of $0.5 \times 0.5$ degree latitude and longitude and covering the 1997-2010 period. We find a strongly significant and quantitatively large impact of mining activities on the likelihood of conflict incidence. We perform numerous sensitivity tests and show that the results are robust to a variety of alternative specifications. According to our estimates, the commodities super-cycle (i.e., the steep increase in mineral prices during the 2000s) accounts for 14 percent to 24 percent of the average violence observed in African countries over 1997-2010.

In terms of mechanisms, our baseline finding that mineral price shocks cause an increase in the risk of conflict is consistent with several potential channels. The presence of natural resources increases rebellion feasibility, boosts the potential for rent-seeking, favors weak state capacity and extractive institutions, exacerbates grievances, and drives down the opportunity cost of rebel recruitment by making production more capital-intensive. In contrast, we do not detect evidence of a migration channel, and our results contradict settings claiming that natural resources could reduce conflict by generating higher local incomes.

Our spatially fine-grained dataset allows us to carry out an in-depth analysis of a specific mechanism, namely the feasibility channel, through which mineral rents fuel fighting capacity and lead to the escalation of violence over space and time. In particular, we document that variations in the prices of minerals extracted in the ethnic homeland of a rebel group have a strong effect on conflicts involving this

\footnotetext{
${ }^{59}$ In Appendix Table 17 we carry out the analogous analysis, but focusing on the specification of column 4 of the baseline Table 2. We also find that control of corruption, Corporate Social Responsibility, and the Great Lakes Region certification scheme tend to decrease the conflict-boosting effect of mineral price shocks, although the results are somewhat weaker than in Table 7. Further, we replicate in Table A.37 in the online Appendix the regressions of Table 7 but for domestic firms. Interestingly, we find that the detrimental effect of mining price spikes as well as the virtues of transparency are confined to foreign firms. Finally, Table A.38 in the online Appendix studies the effect of the Kimberley initiative on war diamonds. We find either no effect or a marginally significant conflict-reducing effect. These results are to be interpreted with caution given the limited source of identification and the drawbacks of the diamond price data mentioned previously.
} 
group elsewhere. Further, we show that gaining the territorial control of a mining area leads rebel groups to intensify and spread their fighting activity elsewhere in the territory in the successive periods, while winning a battle outside a mining area does not have such a conflict diffusion effect. While we see these empirical results as consistent with the feasibility channel, they should not be interpreted as ruling out that additional channels listed above could also be at work.

Our findings have important policy implications. It is likely that mineral extraction relaxes the financing constraints of rebels, because armed groups can sell minerals illicitly on the black market through the benefit of tacit or active support in various areas of society. Our empirical results suggest that one way for domestic governments to dampen rebellion feasibility effects would be to put in place more stringent anticorruption policies, and to support transparency/traceability initiatives in the mining industry. The multinational foreign firms have too their work to do, as we find that mines operated by companies complying with socially responsible practices are less at risk to fuel violence.

\section{APPENDIX}

\section{A. Maps}

\section{Panel A. Conflict events}

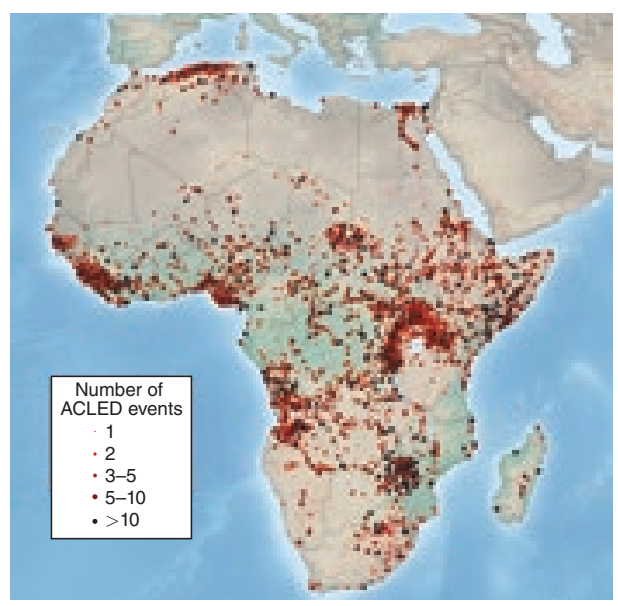

Panel B. Mining areas

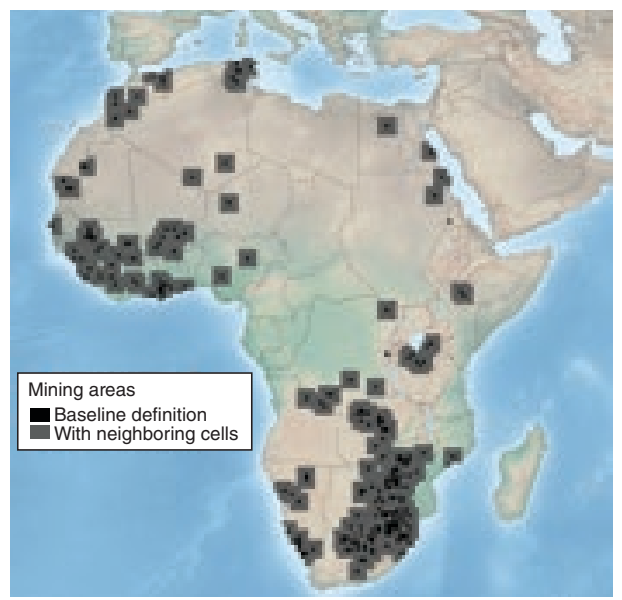

Figure 3. Conflict Events and Mining Areas

Sources: Geolocation of conflict from the Armed Conflict Location and Event dataset (ACLED 2014). Geolocation of active mining areas from Raw Material Data (RMD). 


\section{B. Additional Results}

\section{Panel A. Specification (2)}

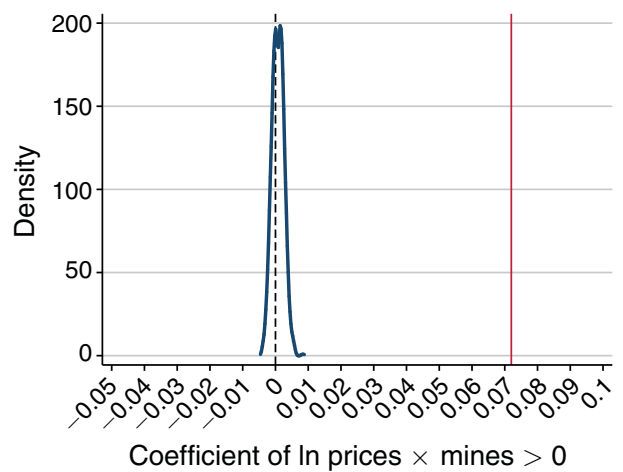

Panel B. Specification (4)

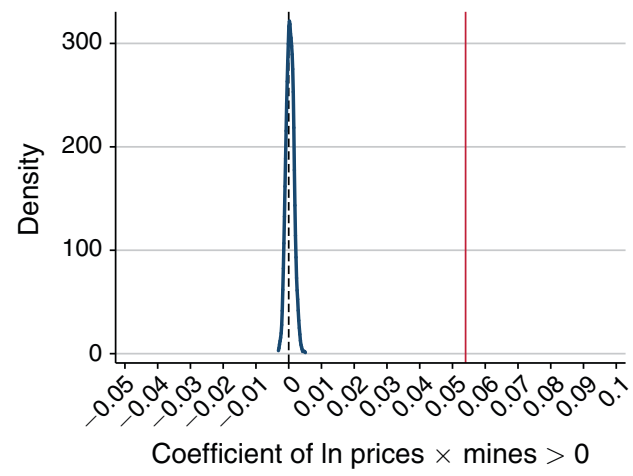

Figure 4. Monte Carlo Sampling Distribution of $(\ln$ price $\times$ mines $>0)$

Note: We draw randomly 1,000 times a main mineral for mining cells and we estimate specifications (2) and (4) of Table 2 with this random $\left(M_{k t} \times \ln p_{k t}^{W}\right)$ variable.

Table 8-Robustness: Alternative Definitions of Mining Areas

\begin{tabular}{|c|c|c|c|c|c|c|c|}
\hline \multirow{3}{*}{$\begin{array}{l}\text { Estimator } \\
\text { Dependent variable } \\
\text { Def. mining area }\end{array}$} & \multicolumn{7}{|c|}{ LPM } \\
\hline & \multicolumn{7}{|c|}{ Conflict incidence } \\
\hline & $\begin{array}{c}V\left(M_{k t}\right)=0 \\
(1)\end{array}$ & $\begin{array}{c}\text { Ever } \\
1997-2010 \\
(2)\end{array}$ & $\begin{array}{c}\text { Mine }(t-1) \\
(3)\end{array}$ & $\begin{array}{l}1 \text { from opening } \\
\text { onward } \\
\text { (4) }\end{array}$ & $\begin{array}{c}\text { Mine in } \\
1997 \\
(5)\end{array}$ & $\begin{array}{c}\text { Mine over } \\
\text { 1992-1996 } \\
(6)\end{array}$ & $\begin{array}{c}\text { Mine over } \\
\text { 1980-1996 } \\
\text { (7) }\end{array}$ \\
\hline $\ln$ price $\times$ mines $>0$ & $\begin{array}{c}0.072 \\
(0.020)\end{array}$ & $\begin{array}{c}0.043 \\
(0.014)\end{array}$ & $\begin{array}{c}0.033 \\
(0.032)\end{array}$ & $\begin{array}{c}0.050 \\
(0.016)\end{array}$ & $\begin{array}{c}0.056 \\
(0.019)\end{array}$ & $\begin{array}{c}0.056 \\
(0.020)\end{array}$ & $\begin{array}{c}0.050 \\
(0.019)\end{array}$ \\
\hline Cell fixed effects & Yes & Yes & Yes & Yes & Yes & Yes & Yes \\
\hline Country $\times$ year fixed effects & Yes & Yes & Yes & Yes & Yes & Yes & Yes \\
\hline Observations & 142,296 & 143,768 & 133,492 & 143,375 & 143,768 & 143,768 & 143,768 \\
\hline
\end{tabular}

Notes: LPM estimations. Conley (1999) standard errors in parentheses, allowing for spatial correlation within a $500 \mathrm{~km}$ radius and for infinite serial correlation. In columns 1 to 5 , ln price main mineral is the world price of the mineral with the highest production over the period (evaluated at 1997 prices) for mining cells, and zero for nonmining cells. Column 1: mines $>0$ is a dummy taking the value 1 if at least 1 mine is active in the cell in year $t$, and we consider only cells in which the mine dummy takes always the same value over the period. Column 2: mine takes the value 1 if the an active mine was observed in the cell at any point over the 1997-2010 period. Column 3: mine $>0$ is a dummy taking the value 1 if at least 1 mine is active in the cell in year $t-1$ (coefficients on noninteracted variables nonreported). Column 4 : mine $>0$ is a dummy taking the value 1 from the first year an active mine is observed over the 1997-2010 period onward, 0 if no active mine was ever recorded, and is coded as missing otherwise. Column 5: mine $>0$ is a dummy taking the value 1 if at least 1 active mine was recorded in the cell in 1997. Column 6: mine $>0$ is a dummy taking the value 1 if at least 1 active mine was recorded in the cell over the 5-year presample period 1992-1996. Column 7: mine $>0$ is a dummy taking the value 1 if at least 1 active mine was ever recorded in the cell in the RMD data (period 1980-1996). 
Table 9-Conflicts and Mineral Prices: $1 \times 1$ Degree Cells

\begin{tabular}{|c|c|c|c|c|c|}
\hline \multirow{4}{*}{$\begin{array}{l}\text { Estimator } \\
\text { Dependent variable } \\
\text { Sample }\end{array}$} & \multicolumn{5}{|c|}{ LPM } \\
\hline & \multicolumn{5}{|c|}{ Conflict incidence } \\
\hline & All & \multicolumn{2}{|c|}{$V\left(M_{k t}\right)=0$} & All & $V\left(M_{k t}\right)=0$ \\
\hline & (1) & $(2)$ & (3) & (4) & $(5)$ \\
\hline mine $>0$ & $\begin{array}{c}0.159 \\
(0.068)\end{array}$ & & & & $\begin{array}{c}0.221 \\
(0.108)\end{array}$ \\
\hline ln price main mineral & $\begin{array}{c}-0.043 \\
(0.036)\end{array}$ & & & & $\begin{array}{c}-0.049 \\
(0.021)\end{array}$ \\
\hline ln price $\times$ mines $>0$ & $\begin{array}{c}0.130 \\
(0.042)\end{array}$ & $\begin{array}{c}0.104 \\
(0.036)\end{array}$ & & $\begin{array}{c}0.118 \\
(0.037)\end{array}$ & $\begin{array}{c}0.154 \\
(0.041)\end{array}$ \\
\hline ln price $\times$ mines $>0$ (ever $)$ & & & $\begin{array}{c}0.068 \\
(0.022)\end{array}$ & & \\
\hline Country $\times$ year fixed effects & Yes & Yes & Yes & No & No \\
\hline Year fixed effects & No & No & No & Yes & Yes \\
\hline Cell fixed effects & Yes & Yes & Yes & Yes & No \\
\hline Neighbor-pairs fixed effects & No & No & No & No & Yes \\
\hline Observations & 37,198 & 36,120 & 37,436 & 36,120 & 9,394 \\
\hline
\end{tabular}

Notes: LPM estimations. Conley (1999) standard errors in parentheses, allowing for spatial correlation within a $500 \mathrm{~km}$ radius and for infinite serial correlation. Variables: mines $>0$ is a dummy taking the value 1 if at least 1 mine is active in the cell in year $t$; mines $>0$ (ever) is a dummy taking the value 1 if at least 1 mine is recorded in the cell at any point over the 1997-2010 period; mines $>0$ (neighboring cells) is a dummy taking the value 1 if at least 1 mine is recorded in neighboring cells of degree 1 and 2 in year $t ; V\left(M_{k t}\right)=0$ means that we consider only cells in which the mine dummy (or dummies in column 3 ) takes always the same value over the period. In all columns, ln price main mineral is the world price of the mineral with the highest production over the period (evaluated at 1997 prices) for mining cells, and zero for nonmining cells. Estimation (1) includes controls for the average level of mineral world price interacted with the mine dummy.

Table 10-Main Mineral Price

\begin{tabular}{|c|c|c|c|c|c|c|}
\hline \multirow{4}{*}{$\begin{array}{l}\text { Estimator } \\
\text { Dependent variable } \\
\text { Robustness } \\
\text { Sample }\end{array}$} & \multicolumn{6}{|c|}{ LPM } \\
\hline & \multicolumn{6}{|c|}{ Conflict incidence } \\
\hline & \multicolumn{2}{|c|}{ Single mineral } & \multicolumn{2}{|c|}{ Stable main mineral } & \multicolumn{2}{|c|}{ Price index } \\
\hline & $\begin{array}{c}V\left(M_{k t}\right)=0 \\
(1)\end{array}$ & $\begin{array}{c}\text { None } \\
(2)\end{array}$ & $\begin{array}{c}V\left(M_{k t}\right)=0 \\
(3)\end{array}$ & $\begin{array}{c}\text { None } \\
(4)\end{array}$ & $\begin{array}{c}V\left(M_{k t}\right)=0 \\
(5)\end{array}$ & $\begin{array}{c}\text { None } \\
(6)\end{array}$ \\
\hline ln price $\times$ mines $>0$ & $\begin{array}{c}0.046 \\
(0.019)\end{array}$ & & $\begin{array}{c}0.068 \\
(0.020)\end{array}$ & & $\begin{array}{c}0.065 \\
(0.020)\end{array}$ & \\
\hline ln price $\times$ mines $>0($ ever $)$ & & $\begin{array}{c}0.040 \\
(0.016)\end{array}$ & & $\begin{array}{c}0.048 \\
(0.015)\end{array}$ & & $\begin{array}{c}0.039 \\
(0.013)\end{array}$ \\
\hline Country $\times$ year fixed effects & Yes & Yes & Yes & Yes & No & No \\
\hline Year fixed effects & No & No & No & No & Yes & Yes \\
\hline Cell fixed effects & Yes & Yes & Yes & Yes & Yes & No \\
\hline Neighbor-pairs fixed effects & No & No & No & No & No & Yes \\
\hline Observations & 141,960 & 143,136 & 142,212 & 143,542 & 142,464 & 144,452 \\
\hline
\end{tabular}

Notes: LPM estimations. Conley (1999) standard errors in parentheses, allowing for spatial correlation within a $500 \mathrm{~km}$ radius and for infinite serial correlation. Variables: mine $>0$ is a dummy taking the value 1 if at least 1 mine is active in the cell in year $t$; mines $>0$ (ever) is a dummy taking the value 1 if at least 1 mine is recorded in the cell at any point over the 1997-2010 period; mines $>0$ (neighboring cells) is a dummy taking the value 1 if at least 1 mine is recorded in neighboring cells of degree 1 and 2 in year $t ; V\left(M_{k t}\right)=0$ means that we consider only cells in which the mine dummy takes always the same value over the period. In columns 1 and 2 , $\ln$ price mineral is the average price of the minerals produced in the cells, with weights equals to the share of each mineral in total production value over the period. In columns 3 to 6 , ln price mineral is the world price of the mineral with the highest production over the period (evaluated at 1997 prices) for mining cells, and zero for nonmining cells. Columns 4 and 5 include only mining cells producing a single mineral over the entire period. Columns 5 and 6 include only cells for which the main mineral is the same for each year of the sample. 
TABle 11-Number of Events

\begin{tabular}{|c|c|c|c|c|c|c|c|c|}
\hline \multirow{5}{*}{$\begin{array}{l}\text { Estimator } \\
\text { Dependent variable }\end{array}$} & \multicolumn{3}{|c|}{ LPM } & \multicolumn{3}{|c|}{ PPML } & \multicolumn{2}{|c|}{ LPM } \\
\hline & \multicolumn{8}{|c|}{ Number of events } \\
\hline & \multicolumn{3}{|c|}{ Dropping Dropping } & \multicolumn{3}{|c|}{ Dropping Dropping } & \multirow{3}{*}{$\begin{array}{c}\log (x+1) \\
(7)\end{array}$} & \multirow{3}{*}{$\begin{array}{c}\text { Inverse } \\
\text { hyperbolic } \\
(8)\end{array}$} \\
\hline & All & top $5 \%$ & $2 \mathrm{SD}$ & All & top $5 \%$ & $2 \mathrm{SD}$ & & \\
\hline & (1) & $(2)$ & (3) & (4) & $(5)$ & $(6)$ & & \\
\hline \multirow{2}{*}{$\begin{array}{l}\text { Sample A. } V\left(\mathrm{M}_{k t}\right)=0 \\
\ln \text { price } \times \text { mines }>0\end{array}$} & & & & & & & & \\
\hline & $\begin{array}{c}0.249 \\
(0.240)\end{array}$ & $\begin{array}{c}0.263 \\
(0.100)\end{array}$ & $\begin{array}{c}0.256 \\
(0155)\end{array}$ & $\begin{array}{c}0.195 \\
(0.283)\end{array}$ & $\begin{array}{c}0.440 \\
(0.197)\end{array}$ & $\begin{array}{c}0.301 \\
(0.239)\end{array}$ & $\begin{array}{l}0.094 \\
(0.032)\end{array}$ & 0.121 \\
\hline & & & & & & & & \\
\hline Cell fixed effects & Yes & Yes & Yes & Yes & Yes & Yes & Yes & Yes \\
\hline Country $\times$ year fixed effects & Yes & Yes & Yes & No & No & No & Yes & Yes \\
\hline Year fixed effects & No & No & No & Yes & Yes & Yes & No & No \\
\hline Observations & 142,296 & 141,894 & 142,163 & 35,210 & 34,769 & 35,064 & 142,296 & 142,296 \\
\hline \multicolumn{9}{|l|}{ Sample B. All } \\
\hline ln price $\times$ mines $>0($ ever $)$ & $\begin{array}{c}0.245 \\
(0.136)\end{array}$ & $\begin{array}{c}0.216 \\
(0.079)\end{array}$ & $\begin{array}{c}0.217 \\
(0.100)\end{array}$ & $\begin{array}{c}0.253 \\
(0.264)\end{array}$ & $\begin{array}{c}0.395 \\
(0.172)\end{array}$ & $\begin{array}{c}0.289 \\
(0.194)\end{array}$ & $\begin{array}{c}0.070 \\
(0.022)\end{array}$ & $\begin{array}{c}0.089 \\
(0.028)\end{array}$ \\
\hline Cell fixed effects & Yes & Yes & Yes & Yes & Yes & Yes & Yes & Yes \\
\hline Country $\times$ year fixed effects & Yes & Yes & Yes & No & No & No & Yes & Yes \\
\hline Year fixed effects & No & No & No & Yes & Yes & Yes & No & No \\
\hline Observations & 143,864 & 143,361 & 143,634 & 35,980 & 35,472 & 35,771 & 143,864 & 143,864 \\
\hline
\end{tabular}

Notes: LPM estimations. Conley (1999) standard errors in parentheses, allowing for spatial correlation within a $500 \mathrm{~km}$ radius and for infinite serial correlation in columns 1 to 3 and 7 to 8 . Standard errors clustered by country in columns 4 to 6 . Variables: mines $>0$ is a dummy taking the value 1 if at least 1 mine is active in the cell in year $t$; mines $>0$ (ever) is a dummy taking the value 1 if at least 1 mine is recorded in the cell at any point over the 19972010 period; $V\left(M_{k t}\right)=0$ means that we consider only cells in which the mine dummy takes always the same value over the period; ln price main mineral is the world price of the mineral with the highest production over the period (evaluated at 1997 prices) for mining cells, and zero for nonmining cells. 
Table 12-Heterogeneous Effects: Cleavages

\begin{tabular}{|c|c|c|c|c|c|c|c|c|}
\hline \multirow{3}{*}{$\begin{array}{l}\text { Estimator } \\
\text { Dependent variable } \\
\text { Sample }\end{array}$} & \multicolumn{8}{|c|}{ LPM } \\
\hline & \multicolumn{8}{|c|}{ Conflict incidence } \\
\hline & $\begin{array}{c}\mathrm{V}\left(M_{k t}\right)=0 \\
(1)\end{array}$ & $\begin{array}{l}\text { All } \\
(2) \\
\end{array}$ & $\begin{array}{c}V\left(M_{k t}\right)=0 \\
(3)\end{array}$ & $\begin{array}{l}\text { All } \\
(4) \\
\end{array}$ & $\begin{array}{c}V\left(M_{k t}\right)=0 \\
(5)\end{array}$ & $\begin{array}{l}\text { All } \\
(6) \\
\end{array}$ & $\begin{array}{c}V\left(M_{k t}\right)=0 \\
(7)\end{array}$ & $\begin{array}{l}\text { All } \\
(8)\end{array}$ \\
\hline ln price $\times$ mines $>0$ & $\begin{array}{c}0.031 \\
(0.026)\end{array}$ & & $\begin{array}{c}0.024 \\
(0.028)\end{array}$ & & $\begin{array}{c}0.043 \\
(0.032)\end{array}$ & & $\begin{array}{c}0.111 \\
(0.054)\end{array}$ & \\
\hline ln price $\times$ mines $>0($ ever $)$ & & $\begin{array}{c}0.027 \\
(0.018)\end{array}$ & & $\begin{array}{c}0.015 \\
(0.020)\end{array}$ & & $\begin{array}{c}0.014 \\
(0.021)\end{array}$ & & $\begin{array}{c}0.095 \\
(0.038)\end{array}$ \\
\hline$\times$ Gini & $\begin{array}{c}0.053 \\
(0.043)\end{array}$ & $\begin{array}{c}0.015 \\
(0.022)\end{array}$ & & & & & & \\
\hline$\times$ ethnic frac. & & & $\begin{array}{c}0.015 \\
(0.040)\end{array}$ & $\begin{array}{c}0.002 \\
(0.025)\end{array}$ & & & & \\
\hline$\times$ religious frac. & & & $\begin{array}{c}0.069 \\
(0.038)\end{array}$ & $\begin{array}{c}0.046 \\
(0.023)\end{array}$ & & & & \\
\hline$\times$ ethnic pol. & & & & & $\begin{array}{c}-0.017 \\
(0.034)\end{array}$ & $\begin{array}{c}0.015 \\
(0.022)\end{array}$ & & \\
\hline$\times$ religious pol. & & & & & $\begin{array}{c}0.081 \\
(0.034)\end{array}$ & $\begin{array}{c}0.042 \\
(0.019)\end{array}$ & & \\
\hline$\times$ indigenous & & & & & & & $\begin{array}{r}-0.044 \\
(0.058)\end{array}$ & $\begin{array}{r}-0.060 \\
(0.041)\end{array}$ \\
\hline Country $\times$ year fixed effects & Yes & Yes & Yes & Yes & Yes & Yes & Yes & Yes \\
\hline Cell fixed effects & Yes & Yes & Yes & Yes & Yes & Yes & Yes & Yes \\
\hline Observations & 95,494 & 96,796 & 127,666 & 129,094 & 127,666 & 129,094 & 129,290 & 130,816 \\
\hline
\end{tabular}

Notes: LPM estimations. Standard errors clustered by country in columns 1 to 6; Conley (1999) standard errors in parentheses, allowing for spatial correlation within a $500 \mathrm{~km}$ radius and for infinite serial correlation in columns 7 and 8. Variables: mines $>0$ is a dummy taking the value 1 if at least 1 mine is active in the cell in year $t$; mines $>0$ (ever) is a dummy taking the value 1 if at least 1 mine is recorded in the cell at any point over the 1997-2010 period; $V\left(M_{k t}\right)=0$ means that we consider only cells in which the mine dummy takes always the same value over the period; In price main mineral is the world price of the mineral with the highest production over the period (evaluated at 1997 prices) for mining cells, and zero for nonmining cells. In columns 1 to 6 , country-level variables are dummies taking the value 1 if the country is above the sample median of the corresponding variable before the start of the period. In columns 1 and 2, higher Gini scores correspond to larger inequality. In columns 7 and 8 the indigenous variable is a dummy taking a value of 1 if all groups in a given cell are indigenous. 
TABle 13-Heterogeneous EfFects: Institutional Quality

\begin{tabular}{|c|c|c|c|c|c|c|}
\hline \multirow{3}{*}{$\begin{array}{l}\text { Estimator } \\
\text { Dependent variable } \\
\text { Sample }\end{array}$} & \multicolumn{6}{|c|}{ LPM } \\
\hline & \multicolumn{6}{|c|}{ Conflict incidence } \\
\hline & $\begin{array}{l}V\left(M_{k t}\right)=0 \\
\quad(1)\end{array}$ & $\begin{array}{l}\text { All } \\
(2)\end{array}$ & $\begin{array}{c}V\left(M_{k t}\right)=0 \\
\quad(3)\end{array}$ & $\begin{array}{l}\text { All } \\
(4)\end{array}$ & $\begin{array}{c}V\left(M_{k t}\right)=0 \\
(5)\end{array}$ & $\begin{array}{l}\text { All } \\
(6)\end{array}$ \\
\hline $\ln$ price $\times$ mines $>0$ & $\begin{array}{c}0.077 \\
(0.051)\end{array}$ & & $\begin{array}{c}0.039 \\
(0.036)\end{array}$ & & $\begin{array}{c}0.090 \\
(0.036)\end{array}$ & \\
\hline ln price $\times$ mines $>0($ ever $)$ & & $\begin{array}{c}0.032 \\
(0.029)\end{array}$ & & $\begin{array}{c}0.053 \\
(0.028)\end{array}$ & & $\begin{array}{c}0.050 \\
(0.024)\end{array}$ \\
\hline$\times$ ICRG & $\begin{array}{c}0.002 \\
(0.059)\end{array}$ & $\begin{array}{c}0.020 \\
(0.033)\end{array}$ & & & & \\
\hline$\times$ gov. effectiv. & & & $\begin{array}{c}-0.053 \\
(0.046)\end{array}$ & $\begin{array}{c}0.024 \\
(0.034)\end{array}$ & & \\
\hline$\times$ rule of law & & & $\begin{array}{c}0.027 \\
(0.038)\end{array}$ & $\begin{array}{l}0.030 \\
(0.047)\end{array}$ & & \\
\hline$\times$ voice and accoun. & & & $\begin{array}{c}0.107 \\
(0.048)\end{array}$ & $\begin{array}{l}0.004 \\
(0.043)\end{array}$ & & \\
\hline$\times$ control of corruption & & & $\begin{array}{c}-0.043 \\
(0.040)\end{array}$ & $\begin{array}{r}-0.064 \\
(0.029)\end{array}$ & & \\
\hline$\times$ polity IV & & & & & $\begin{array}{c}-0.027 \\
(0.045)\end{array}$ & $\begin{array}{c}-0.008 \\
(0.027)\end{array}$ \\
\hline Country $\times$ year fixed effects & Yes & Yes & Yes & Yes & Yes & Yes \\
\hline Cell fixed effects & Yes & Yes & Yes & Yes & Yes & Yes \\
\hline Observations & 115,626 & 117,082 & 131,628 & 133,126 & 131,712 & 133,210 \\
\hline
\end{tabular}

Notes: LPM estimations. Standard errors clustered by country in parentheses. Variables: mines $>0$ is a dummy taking the value 1 if at least 1 mine is active in the cell in year $t$; mines $>0$ (ever) is a dummy taking the value 1 if at least 1 mine is recorded in the cell at any point over the 1997-2010 period; $V\left(M_{k t}\right)=0$ means that we consider only cells in which the mine dummy takes always the same value over the period; ln price main mineral is the world price of the mineral with the highest production over the period (evaluated at 1997 prices) for mining cells, and zero for nonmining cells. Country-level variables are dummies taking the value 1 if the country is above the sample median of the corresponding variable before the start of the period.

Table 14-Heterogeneous Effects: Minerals' Capital Intensity

\begin{tabular}{|c|c|c|c|c|c|c|}
\hline \multirow{3}{*}{$\begin{array}{l}\text { Estimator } \\
\text { Dependent variable } \\
\text { Sample }\end{array}$} & \multicolumn{6}{|c|}{ LPM } \\
\hline & \multicolumn{6}{|c|}{ Conflict incidence } \\
\hline & $\begin{array}{c}V\left(M_{k t}\right)=0 \\
(1)\end{array}$ & $\begin{array}{l}\text { All } \\
(2)\end{array}$ & $\begin{array}{c}V\left(M_{k t}\right)=0 \\
(3)\end{array}$ & $\begin{array}{l}\text { All } \\
(4)\end{array}$ & $\begin{array}{c}V\left(M_{k t}\right)=0 \\
(5)\end{array}$ & $\begin{array}{l}\text { All } \\
(6)\end{array}$ \\
\hline $\ln$ price $\times$ mines $>0$ & $\begin{array}{c}0.119 \\
(0.119)\end{array}$ & & $\begin{array}{c}0.089 \\
(0.026)\end{array}$ & & $\begin{array}{c}0.069 \\
(0.022)\end{array}$ & \\
\hline ln price $\times$ mines $>0($ ever $)$ & & $\begin{array}{c}0.087 \\
(0.048)\end{array}$ & & $\begin{array}{c}0.078 \\
(0.023)\end{array}$ & & $\begin{array}{c}0.041 \\
(0.014)\end{array}$ \\
\hline$\times$ open cast & $\begin{array}{c}0.078 \\
(0.650)\end{array}$ & $\begin{array}{c}-0.042 \\
(0.119)\end{array}$ & & & & \\
\hline$x$ energy intensity & & & $\begin{array}{c}-0.000 \\
(0.000)\end{array}$ & $\begin{array}{c}-0.000 \\
(0.000)\end{array}$ & & \\
\hline$\times$ mine age & & & & & $\begin{array}{c}0.001 \\
(0.002)\end{array}$ & $\begin{array}{c}0.002 \\
(0.002)\end{array}$ \\
\hline Country $\times$ year fixed effects & Yes & Yes & Yes & Yes & Yes & Yes \\
\hline Cell fixed effects & Yes & Yes & Yes & Yes & Yes & Yes \\
\hline Observations & 141,344 & 141,946 & 141,782 & 142,192 & 142,221 & 143,789 \\
\hline
\end{tabular}

Notes: LPM estimations. Conley (1999) standard errors in parentheses, allowing for spatial correlation within a $500 \mathrm{~km}$ radius and for infinite serial correlation. Variables: mines $>0$ is a dummy taking the value 1 if at least 1 mine is active in the cell in year $t$; mines $>0$ (ever) is a dummy taking the value 1 if at least 1 mine is recorded in the cell at any point over the 1997-2010 period; $V\left(M_{k t}\right)=0$ means that we consider only cells in which the mine dummy takes always the same value over the period; ln price main mineral is the world price of the mineral with the highest production over the period (evaluated at 1997 prices) for mining cells, and zero for nonmining cells; open cast is the average percentage of mines using open-pit mining method in Africa over the period; energy intensity is the ratio of $\ln ($ energy/production) over $\ln ($ employees/production); mine age is the number of years since the first mining activity was observed. 
Table 15-Heterogeneous Effects: Minerals' Lootability

\begin{tabular}{|c|c|c|c|c|c|c|}
\hline \multirow{3}{*}{$\begin{array}{l}\text { Estimator } \\
\text { Dependent variable } \\
\text { Sample }\end{array}$} & \multicolumn{6}{|c|}{ LPM } \\
\hline & \multicolumn{6}{|c|}{ Conflict incidence } \\
\hline & $\begin{array}{l}V\left(M_{k t}\right)=0 \\
(1)\end{array}$ & $\begin{array}{l}\text { All } \\
(2)\end{array}$ & $\begin{array}{c}V\left(M_{k t}\right)=0 \\
(3)\end{array}$ & $\begin{array}{l}\text { All } \\
(4)\end{array}$ & $\begin{array}{c}V\left(M_{k t}\right)=0 \\
(5)\end{array}$ & $\begin{array}{l}\text { All } \\
(6)\end{array}$ \\
\hline ln price $\times$ mines $>0$ : low price & $\begin{array}{c}0.046 \\
(0.027)\end{array}$ & & & & & \\
\hline ln price $\times$ mines $>0$ : high price & $\begin{array}{c}0.065 \\
(0.025)\end{array}$ & & & & & \\
\hline ln price $\times$ mines $>0$ (ever): low price & & $\begin{array}{c}0.021 \\
(0.020)\end{array}$ & & & & \\
\hline ln price $\times$ mines $>0($ ever $)$ : high price & & $\begin{array}{c}0.044 \\
(0.017)\end{array}$ & & & & \\
\hline ln price $\times$ mines $>0$ & & & $\begin{array}{c}0.117 \\
(0.050)\end{array}$ & & $\begin{array}{c}0.088 \\
(0.024)\end{array}$ & \\
\hline ln price $\times$ mines $>0($ ever $)$ & & & & $\begin{array}{c}0.027 \\
(0.048)\end{array}$ & & $\begin{array}{c}0.054 \\
(0.017)\end{array}$ \\
\hline$\times$ high rents & & & $\begin{array}{c}-0.061 \\
(0.054)\end{array}$ & $\begin{array}{c}0.010 \\
(0.050)\end{array}$ & & \\
\hline$\times$ ore concentration & & & & & $\begin{array}{r}-0.174 \\
(0.059)\end{array}$ & $\begin{array}{c}-0.166 \\
(0.056)\end{array}$ \\
\hline Country $\times$ year fixed effects & Yes & Yes & Yes & Yes & Yes & Yes \\
\hline Cell fixed effects & Yes & Yes & Yes & Yes & Yes & Yes \\
\hline Observations & 142,674 & 144,356 & 142,674 & 144,356 & 142,170 & 143,262 \\
\hline
\end{tabular}

Notes: LPM estimations. Conley (1999) standard errors in parentheses, allowing for spatial correlation within a $500 \mathrm{~km}$ radius and for infinite serial correlation. Variables: mines $>0$ is a dummy taking the value 1 if at least 1 mine is active in the cell in year $t$; mines $>0$ (ever) is a dummy taking the value 1 if at least 1 mine is recorded in the cell at any point over the 1997-2010 period; $V\left(M_{k t}\right)=0$ means that we consider only cells in which the mine dummy takes always the same value over the period; ln price main mineral is the world price of the mineral with the highest production over the period (evaluated at 1997 prices) for mining cells, and zero for nonmining cells; high (respectively low) price means above (below) the sample median of prices in US\$ per ton in 1997; high rents means that the ratio of mineral price over mineral-specific average costs for all African mines is above the sample median; ore concentration is the average concentration of the metal in the corresponding ore.

Table 16-Mineral Price, Firm Ownership, and Conflicts (Robustness)

\begin{tabular}{|c|c|c|c|c|c|c|}
\hline \multirow{3}{*}{$\begin{array}{l}\text { Estimator } \\
\text { Dependent variable } \\
\text { Events }\end{array}$} & \multicolumn{6}{|c|}{ LPM } \\
\hline & \multicolumn{6}{|c|}{ Conflict incidence } \\
\hline & $\begin{array}{l}\text { All } \\
(1)\end{array}$ & $\begin{array}{l}\text { Battles } \\
(2)\end{array}$ & $\begin{array}{l}\text { All } \\
\text { (3) }\end{array}$ & $\begin{array}{c}\text { Battles } \\
\text { (4) }\end{array}$ & $\begin{array}{l}\text { All } \\
(5)\end{array}$ & $\begin{array}{l}\text { Battles } \\
(6)\end{array}$ \\
\hline ln price $\times$ mines $>0 \times$ foreign firms & $\begin{array}{c}0.058 \\
(0.021)\end{array}$ & $\begin{array}{c}0.010 \\
(0.009)\end{array}$ & & & & \\
\hline ln price $\times$ mines $>0 \times$ dom. private firms & $\begin{array}{l}0.018 \\
(0.014)\end{array}$ & $\begin{array}{c}-0.001 \\
(0.003)\end{array}$ & $\begin{array}{c}0.018 \\
(0.014)\end{array}$ & $\begin{array}{c}-0.001 \\
(0.003)\end{array}$ & $\begin{array}{c}-0.011 \\
(0.024)\end{array}$ & $\begin{array}{c}-0.004 \\
(0.007)\end{array}$ \\
\hline In price $\times$ mines $>0 \times$ dom. public firms & $\begin{array}{c}0.032 \\
(0.034)\end{array}$ & $\begin{array}{c}-0.005 \\
(0.019)\end{array}$ & $\begin{array}{c}0.031 \\
(0.034)\end{array}$ & $\begin{array}{r}-0.006 \\
(0.019)\end{array}$ & $\begin{array}{c}0.032 \\
(0.034)\end{array}$ & $\begin{array}{c}-0.005 \\
(0.019)\end{array}$ \\
\hline ln price $\times$ mines $>0 \times$ fgn firms $($ col. $)$ & & & $\begin{array}{c}0.007 \\
(0.031)\end{array}$ & $\begin{array}{c}-0.012 \\
(0.017)\end{array}$ & $\begin{array}{c}-0.034 \\
(0.037)\end{array}$ & $\begin{array}{r}-0.016 \\
(0.018)\end{array}$ \\
\hline ln price $\times$ mines $>0 \times$ fgn firms (non col.) & & & $\begin{array}{c}0.071 \\
(0.024)\end{array}$ & $\begin{array}{c}0.015 \\
(0.010)\end{array}$ & $\begin{array}{c}0.043 \\
(0.020)\end{array}$ & $\begin{array}{c}0.013 \\
(0.009)\end{array}$ \\
\hline ln price $\times$ mines $>0 \times$ large firms & & & & & $\begin{array}{c}0.061 \\
(0.033)\end{array}$ & $\begin{array}{c}0.006 \\
(0.013)\end{array}$ \\
\hline Country $\times$ year fixed effects & Yes & Yes & Yes & Yes & Yes & Yes \\
\hline Cell fixed effects & Yes & Yes & Yes & Yes & Yes & Yes \\
\hline Observations & 143,542 & 143,542 & 143,542 & 143,542 & 143,542 & 143,542 \\
\hline
\end{tabular}

Notes: LPM estimations. Conley (1999) standard errors in parentheses, allowing for spatial correlation within a 500 $\mathrm{km}$ radius and for infinite serial correlation. Variables: mines $>0$ (ever) is a dummy taking the value 1 if at least 1 mine is recorded in the cell at any point over the 1997-2010 period; $V\left(M_{k t}\right)=0$ means that we consider only cells in which the mine dummy takes always the same value over the period; ln price main mineral is the world price of the mineral with the highest production over the period (evaluated at 1997 prices) for mining cells, and zero for nonmining cells. The company characteristics (foreign, domestic public, domestic private, etc.) denote the share of mines owned by a given category at the beginning of the period. Cells containing only mines with missing ownership information are dropped. 
Table 17-Heterogeneous Effects: The Role of Transparency (Robustness)

\begin{tabular}{|c|c|c|c|c|c|c|c|c|c|c|}
\hline \multirow{3}{*}{$\begin{array}{l}\text { Estimator } \\
\text { Dependent variable } \\
\text { Events }\end{array}$} & \multicolumn{10}{|c|}{ LPM } \\
\hline & \multicolumn{10}{|c|}{ Conflict incidence } \\
\hline & $\begin{array}{l}\text { All } \\
\text { (1) }\end{array}$ & $\begin{array}{c}\text { Battles } \\
(2)\end{array}$ & $\begin{array}{l}\text { All } \\
\text { (3) }\end{array}$ & $\begin{array}{c}\text { Battles } \\
\text { (4) }\end{array}$ & $\begin{array}{l}\text { All } \\
(5)\end{array}$ & $\begin{array}{c}\text { Battles } \\
(6)\end{array}$ & $\begin{array}{l}\text { All } \\
\text { (7) }\end{array}$ & $\begin{array}{c}\text { Battles } \\
(8)\end{array}$ & $\begin{array}{l}\text { All } \\
(9)\end{array}$ & $\begin{array}{c}\text { Battles } \\
(10)\end{array}$ \\
\hline ln price $\times$ mines $>0($ ever $)$ & $\begin{array}{l}-0.022 \\
(0.015)\end{array}$ & $\begin{array}{l}-0.002 \\
(0.010)\end{array}$ & $\begin{array}{l}-0.001 \\
(0.018)\end{array}$ & $\begin{array}{c}0.011 \\
(0.010)\end{array}$ & $\begin{array}{l}-0.014 \\
(0.016)\end{array}$ & $\begin{array}{c}0.006 \\
(0.010)\end{array}$ & $\begin{array}{l}-0.008 \\
(0.013)\end{array}$ & $\begin{array}{c}0.002 \\
(0.007)\end{array}$ & $\begin{array}{l}-0.005 \\
(0.012)\end{array}$ & $\begin{array}{c}0.006 \\
(0.007)\end{array}$ \\
\hline$\times$ large firms & $\begin{array}{c}0.137 \\
(0.031)\end{array}$ & $\begin{array}{c}0.010 \\
(0.016)\end{array}$ & $\begin{array}{c}0.155 \\
(0.044)\end{array}$ & $\begin{array}{c}0.011 \\
(0.018)\end{array}$ & $\begin{array}{c}0.136 \\
(0.032)\end{array}$ & $\begin{array}{c}0.004 \\
(0.017)\end{array}$ & $\begin{array}{c}0.133 \\
(0.032)\end{array}$ & $\begin{array}{c}0.004 \\
(0.016)\end{array}$ & $\begin{array}{c}0.133 \\
(0.032)\end{array}$ & $\begin{array}{c}0.003 \\
(0.016)\end{array}$ \\
\hline$\times$ control of corruption & $\begin{array}{l}-0.044 \\
(0.022)\end{array}$ & $\begin{array}{l}-0.035 \\
(0.017)\end{array}$ & & & & & & & & \\
\hline$\times$ firm CSR $(\mathrm{ICMM})$ & & & $\begin{array}{l}-0.103 \\
(0.056)\end{array}$ & $\begin{array}{l}-0.040 \\
(0.020)\end{array}$ & & & & & & \\
\hline$\times$ tracea. init. (EITI, request) & & & & & $\begin{array}{c}0.001 \\
(0.002)\end{array}$ & $\begin{array}{c}0.000 \\
(0.001)\end{array}$ & & & & \\
\hline$\times$ tracea. init. (EITI, compliance) & & & & & & & $\begin{array}{c}0.001 \\
(0.003)\end{array}$ & $\begin{array}{c}0.006 \\
(0.005)\end{array}$ & & \\
\hline$\times$ tracea. init. $(\mathrm{GLR})$ & & & & & & & & & $\begin{array}{l}-0.002 \\
(0.001)\end{array}$ & $\begin{array}{c}0.001 \\
(0.002)\end{array}$ \\
\hline Country $\times$ year fixed effects & Yes & Yes & Yes & Yes & Yes & Yes & Yes & Yes & Yes & Yes \\
\hline Cell fixed effects & Yes & Yes & Yes & Yes & Yes & Yes & Yes & Yes & Yes & Yes \\
\hline Observations & 131,908 & 131,908 & 142,562 & 142,562 & 142,548 & 142,548 & 142,548 & 142,548 & 142,548 & 142,548 \\
\hline
\end{tabular}

Notes: LPM estimations. Conley (1999) standard errors in parentheses, allowing for spatial correlation within a $500 \mathrm{~km}$ radius and for infinite serial correlation. Sample restricted to nonmining cells and cells for which foreign-owned mines represent the largest share. Variables: mines $>0$ (ever) is a dummy taking the value 1 if at least 1 mine is recorded in the cell at any point over the 1997-2010 period; $V\left(M_{k t}\right)=0$ means that we consider only cells in which the mine dummy takes always the same value over the period; ln price main mineral is the world price of the mineral with the highest production over the period (evaluated at 1997 prices) for mining cells, and zero for nonmining cells. See main text for a description of the various transparency variables.

\section{REFERENCES}

Acemoglu, Daron, Camilo García-Jimeno, and James A. Robinson. 2012. "Finding Eldorado: Slavery and Long-Run Development in Colombia." Journal of Comparative Economics 40 (4): 534-64.

-Andersen, Jørgen Juel, and Silje Aslaksen. 2008. "Constitutions and the Resource Curse." Journal of Development Economics 87 (2): 227-46.

Angrist, Joshua D., and Adriana D. Kugler. 2008. "Rural Windfall or a New Resource Curse? Coca, Income, and Civil Conflict in Colombia." Review of Economics and Statistics 90 (2): 191-215.

-Aragón, Fernando M., and Juan Pablo Rud. 2013. "Natural Resources and Local Communities: Evidence from a Peruvian Gold Mine.” American Economic Journal: Economic Policy 5 (2): 1-25.

-Bazzi, Samuel, and Christopher Blattman. 2014. "Economic Shocks and Conflict: Evidence from Commodity Prices." American Economic Journal: Macroeconomics 6 (4): 1-38.

- Bell, Curtis, and Scott Wolford. 2015. "Oil Discoveries, Shifting Power, and Civil Conflict." International Studies Quarterly 59 (3): 517-30.

- Berman, Nicolas, and Mathieu Couttenier. 2015. "External Shocks, Internal Shots: The Geography of Civil Conflicts." Review of Economics and Statistics 97 (4): 758-76.

Berman, Nicolas, Mathieu Couttenier, Dominic Rohner, and Mathias Thoenig. 2017. "This Mine Is Mine! How Minerals Fuel Conflicts in Africa: Dataset.” American Economic Review. https://doi. org/10.1257/aer.20150774.

-Besley, Timothy, and Torsten Persson. 2011. "The Logic of Political Violence." Quarterly Journal of Economics 126 (3): 1411-45.

Besley, Timothy, and Marta Reynal-Querol. 2014. "The Legacy of Historical Conflict: Evidence from Africa." American Political Science Review 108 (2): 319-36.

-Buonanno, Paolo, Ruben Durante, Giovanni Prarolo, and Paolo Vanin. 2015. "Poor Institutions, Rich Mines: Resource Curse in the Origins of the Sicilian Mafia.” Economic Journal 125 (586): F175-202.

Cain, P. J., and A. G. Hopkins. 2016. British Imperialism: 1688-2015. New York: Routledge. 
Campbell, Greg. 2002. Blood Diamonds: Tracing the Deadly Path of the World's Most Precious Stones. Boulder, CO: Westview Press.

Carter, Colin A., Gordon C. Rausser, and Aaron Smith. 2011. "Commodity Booms and Busts." Annual Review of Resource Economics 3 (1): 87-118.

Caselli, Francesco, and Wilbur John Coleman II. 2013. "On the Theory of Ethnic Conflict.” Journal of the European Economic Association 11: 161-92.

-Caselli, Francesco, Massimo Morelli, and Dominic Rohner. 2015. “The Geography of Interstate Resource Wars." Quarterly Journal of Economics 130 (1): 267-315.

-Cederman, Lars-Erik, Halvard Buhaug, and Jan Ketil Rød. 2009. "Ethno-Nationalist Dyads and Civil War: A GIS-Based Analysis.” Journal of Conflict Resolution 53 (4): 496-525.

Collier, Paul, and Anke Hoeffler. 2004. "Greed and Grievance in Civil War." Oxford Economic Papers 56 (4): 563-95.

Collier, Paul, Anke Hoeffler, and Dominic Rohner. 2009. "Beyond Greed and Grievance: Feasibility and Civil War." Oxford Economic Papers 61 (1): 1-27.

Conley, T. G. 1999. "GMM Estimation with Cross Sectional Dependence." Journal of Econometrics $92(1): 1-45$.

Cotet, Anca M., and Kevin K. Tsui. 2013. "Oil and Conflict: What Does the Cross Country Evidence Really Show?” American Economic Journal: Macroeconomics 5 (1): 49-80.

Couttenier, Mathieu, Pauline Grosjean, and Marc Sangnier. Forthcoming. "The Wild West Is Wild: The Homicide Resource Curse.” Journal of the European Economic Association.

Dal Bó, Ernesto, and Pedro Dal Bó. 2011. "Workers, Warriors, and Criminals: Social Conflict in General Equilibrium." Journal of the European Economic Association 9 (4): 646-77.

De Soysa, Indra. 2002. "Paradise Is a Bazaar? Greed, Creed, and Governance in Civil War, 1989-99." Journal of Peace Research 39 (4): 395-416.

Dietrich, Christian. 2000. "Power Struggles in the Diamond Fields." In Angola's War Economy: The Role of Oil and Diamonds, edited by Jakkie Cilliers and Christian Dietrich. Pretoria: Institute for Security Studies (ISS).

Dube, Oendrila, and Suresh Naidu. 2015. "Bases, Bullets, and Ballots: The Effect of U.S. Military Aid on Political Conflict in Colombia." Journal of Politics 77 (1): 249-67.

Dube, Oeindrila, and Juan F. Vargas. 2013. "Commodity Price Shocks and Civil Conflict: Evidence from Colombia." Review of Economic Studies 80 (4): 1384-1421.

-Esteban, Joan, Massimo Morelli, and Dominic Rohner. 2015. "Strategic Mass Killings." Journal of Political Economy 123 (5): 1087-1132.

Fearon, James D. 2004. "Why Do Some Civil Wars Last So Much Longer than Others?" Journal of Peace Research 41 (3): 275-301.

-Fearon, James D. 2005. "Primary Commodity Exports and Civil War." Journal of Conflict Resolution 49 (4): 483-507.

-Fearon, James, and David Laitin. 2003. "Ethnicity, Insurgency, and Civil War." American Political Science Review 97 (1): 75-90.

Global Witness. 2016. River of Gold: How the State Lost Out in an Eastern Congo Gold Boom, while Armed Groups, a Foreign Mining Company and Provincial Authorities Pocketed Millions. London: Global Witness.

-Grossman, Herschel I., and Juan Mendoza. 2003. "Scarcity and Appropriative Competition." European Journal of Political Economy 19 (4): 747-58.

-Guidolin, Massimo, and Eliana La Ferrara. 2007. "Diamonds Are Forever, Wars Are Not: Is Conflict Bad for Private Firms?” American Economic Review 97 (5): 1978-93.

Guimaraes, Paulo, and Pedro Portugal. 2010. "A Simple Feasible Alternative Procedure to Estimate Models with High-Dimensional Fixed Effects.” Stata Journal 10: 628-49.

Hargreaves, David, and S. Fromson. 1983. World Index of Strategic Minerals: Production, Exploitation and Risk. Hampshire, UK: Gower.

Heffernan, Ian. 2016. "Peace Diamonds: Combating Civil War with a Diamond Certification Scheme." https://sites.google.com/site/ianheffernaneconomics/ (accessed May, 2016).

-Hodler, Roland. 2006. "The Curse of Natural Resources in Fractionalized Countries." European Economic Review 50 (6): 1367-86.

Hsiang, Solomon, Kyle Meng, and Mark Cane. 2011. "Civil Conflicts Are Associated with the Global Climate." Nature 476: 438-41.

Human Rights Watch. 2005. The Curse of Gold: Democratic Republic of Congo. New York: Human Rights Watch.

Humphreys, David. 2010. “The Great Metals Boom: A Retrospective.” Resources Policy 35 (1): 1-13.

Humphreys, Macartan. 2005. "Natural Resources, Conflict, and Conflict Resolution: Uncovering the Mechanisms." Journal of Conflict Resolution 49 (4): 508-37. 
International Labour Office (ILO). 1990. New Processes in Mines Other than Coal Mines: Their Effects on Employment and Training Requirements and the Need for Employment and Social Policies to Cope with These Developments. Geneva, Switzerland: International Labour Organisation.

Kaufmann, Daniel, Aart Kraay, and Massimo Mastruzzi. 2013. Worldwide Governance Indicators: Dataset.

Knutsen, Carl Henrik, Andreas Kotsadam, Eivind Hammersmark Olsen, and Tore Wig. 2017. "Mining and Local Corruption in Africa." American Journal of Political Science 61 (2): 320-34.

König, Michael, Dominic Rohner, Mathias Thoenig, and Fabrizio Zilibotti. Forthcoming. "Networks in Conflict: Theory and Evidence from the Great War of Africa." Econometrica.

Kotsadam, Andreas, and Anja Tolonen. 2016. "African Mining, Gender, and Local Employment." World Development 83: 325-39.

Le Billon, Philippe. 2001. "The Political Ecology of War: Natural Resources and Armed Conflicts." Political Geography 20 (5): 561-84.

Lei, Yu-Hsiang, and Guy Michaels. 2014. "Do Giant Oil Field Discoveries Fuel Internal Armed Conflicts?" Journal of Development Economics 110: 139-57.

Lujala, Paivi. 2009. "Deadly Combat over Natural Resources: Gems, Petroleum, Drugs, and the Severity of Armed Civil Conflict." Journal of Conflict Resolution 53 (1): 50-71.

Lujala, Paivi. 2010. "The Spoils of Nature: Armed Civil Conflict and Rebel Access to Natural Resources." Journal of Peace Research 47 (1): 15-28.

Lujala, Paivi, Nils Petter Gleditsch, and Elisabeth Gilmore. 2005. "A Diamond Curse? Civil War and a Lootable Resource.” Journal of Conflict Resolution 49 (4): 538-62.

Maystadt, Jean-François, Giacomo De Luca, Petros G. Sekeris, and John Ulimwengu. 2014. "Mineral Resources and Conflicts in DRC: A Case of Ecological Fallacy?" Oxford Economic Papers 66 (3): 721-49.

Mehlum, Halvor, Karl Moene, and Ragnar Torvik. 2006. "Institutions and the Resource Curse." Economic Journal 116 (508): 1-20.

Michalopoulos, Stelios, and Elias Papaioannou. 2016. "The Long-Run Effects of the Scramble for Africa." American Economic Review 106 (7): 1802-48.

Morelli, Massimo, and Dominic Rohner. 2015. "Resource Concentration and Civil Wars." Journal of Development Economics 117: 32-47.

-Nunn, Nathan, and Nancy Qian. 2014. "US Food Aid and Civil Conflict." American Economic Review 104 (6): 1630-66.

-Papyrakis, Elissaios, Matthias Rieger, and Emma Gilberthorpe. 2017. "Corruption and the Extractive Industries Transparency Initiative.” Journal of Development Studies 53 (2): 295-309.

Polity IV. 2013. Polity IV Individual Country Regime Trends, 1946-2013. Dataset. www.systemicpeace. org/polity/polity4.htm (accessed April 6, 2017).

Raleigh, Clionadh, Andrew Linke, and Caitriona Dowd. 2014. Armed Conflict Location and Event Data Project (ACLED) Codebook Version 3. Oslo: Peace Research Institute Oslo. http://www. acleddata.com/data/acled-versions-1-6-data-1997-2015/ (accessed April 6, 2016).

- Reuveny, Rafael, and John W. Maxwell. 2001. "Conflict and Renewable Resources.” Journal of Conflict Resolution 45 (6): 719-42.

Reynal-Querol, Marta. 2014. Data on Ethnic and Religious Fractionalization and Polarization. Dataset. http://84.89.132.1/ reynal/data_web.htm (accessed April 6, 2017).

- Ross, Michael L. 2004. "What Do We Know about Natural Resources and Civil War?" Journal of Peace Research 41 (3): 337-56.

-Ross, Michael. 2006. "A Closer Look at Oil, Diamonds, and Civil War." Annual Review of Political Science 9: 265-300.

Sanchez de la Sierra, Raul. 2015. "On the Origin of States: Stationary Bandits and Taxation in Eastern Congo.” https://raulsanchezdelasierra.com/papers/ (accessed May, 2016).

Smits, Joeri, Yibekal Tessema, Takuto Sakamoto, and Richard Schodde. 2016. "The InequalityResource Curse of Conflict: Heterogeneous Effects of Mineral Deposit Discoveries.” World Institute for Development Economic Research Working Paper wp2016-046.

Solt, Frederick. 2014. The Standardized World Income Inequality Database. https://dataverse.harvard. edu/dataset.xhtml?persistentId=hdl:1902.1/11992 (accessed April 6, 2017).

Stockwell, Sarah. 2000. The Business of Decolonization: British Business Strategies in the Gold Coast. Oxford: Oxford University Press.

Weidmann, Nils, Jan Ketil Rød, and Lars-Erik Cederman. 2010. "Representing Ethnic Groups in Space: A New Dataset.” Journal of Peace Research 47 (4): 491-99.

White, Nicholas J. 2000. "The Business and the Politics of Decolonization: The British Experience in the Twentieth Century." Economic History Review 53 (3): 544-64. 